\title{
THE INTERNATIONAL COFFEE AGREEMENT: A CASE HISTORY IN NEGOTIATION
}

RICHARD B. BILDER*

\section{INTRODUCTION}

On July I, Ig63, the International Coffee Agreement, I962 entered provisionally into force among thirty-seven countries, thereby successfully culminating years of effort to establish a global system regulating commerce in one of the world's most important and troublesome commodities.

Briefly, the five-year Agreement, which replaces a more limited short-term Agreement, is designed to stabilize the price of coffee and to bring about long-term equilibrium between coffee production and consumption. Its most important feature is a comprehensive system of export quotas which will limit supplies put on the market by exporting Members to estimated levels of demand. In order to police these quotas, all coffee shipments by Members must be accompanied by certificates showing the coffee's origin. Importing Members will prohibit imports of coffee from other Members without such certificates, and will, in certain circumstances, impose limitations on imports of coffee from non-Members. The Members also agree to study and to undertake measures to progressively reduce overproduction and stocks and to increase coffee consumption. To administer the Agreement, a new international institution-the International Coffee Organization-is established and given broad powers.

Despite the Agreement's prosaic title and technical character, it deserves study for several reasons.

First, the Coffee Agreement is one of the most significant international economic agreements negotiated in recent years. Its provisions will affect more than one and three-quarter billion dollars in world trade and its membership may eventually include more than seventy countries-two-thirds of the nations of the world. It will have a vital and immediate impact on the lives of almost twenty million people in over thirty countries, and an indirect effect on hundreds of millions more. And because of the great dependence of many countries in Latin America and Africa on coffee exports, the success or failure of the Agreement may profoundly influence the political and economic future of two continents.

Second, the Coffee Agreement is the latest and most far-reaching of a growing

* LL.B. I956, Harvard Law School. Office of the Iegal Adviser, United States Department of State. Member of the U.S. Delegation and Chairman of the Legal and Drafting Group, United Nations Coffee Conference, 1962 .

The opinions expressed are solely those of the author and do not necessarily reflect the views or policies of the Department of State or represent any official interpretation of the International Coffee Agreement, Ig62. 
and increasingly important series of such commodity arrangements. ${ }^{1}$ Similar agreements are presently in force covering wheat, sugar, tin, and olive oil, ${ }^{2}$ and an agreement on cocoa may be reached in the very near future. Increased international concern for the special problems of primary commodities and of the underdeveloped countries which produce them ${ }^{3}$ have led to proposals for other agreements covering

1 This issue of Law and Contemporary Problems constitutes the most comprehensive recent survey of international commodity agreements. A brief general introduction to the subject is contained in Lawrence W. Towle, International Trade and Commercial Policy ch. 28 (with suggested readings) (2d ed. 1956). For other recent discussions, see "X," Three International Commodity Agreements, 35 Brit. Yb. Int'l L. 240 (1960); International National Consultants, Inc., Commodity Problems IN LATIN AMrerica ch. 4 ("International Commodity Agreements") (I959)-Study No. 2 of Compilation of Studies on United States-Latin American Relations, prepared under the direction of the Subcommittee on American Republic Affairs of the Senate Committee on Foreign Relations, S. Doc. No. 125, 86th Cong., 2d Sess. I59 (1960); Coffec Study Group, Historical Review of Efforts to Stabilize the Coffee Market and of International Agreements-Proposals for a Long-Term Agreement (Ist rev. Feb. 15, 1961), pp. 49-8I, which is Part VI of the Io-part Coffee Study Group's study, ThE WORLd Coffee Problens: PreseNT Status of the Industry and Future Prospects (1960-62); and Leon Baranyai, History of ComModity AgreEanents (InTERnational Bank for Reconstruction and DevelopMent Rep. No. EC-74a) (I959).

${ }^{2}$ Primary commodity agreements other than the International Coffee Agreement, 1962, currently in force are: the International Wheat Agreement, I962, T.I.A.S. No. 5115; the International Sugar Agreement of 1958, T.I.A.S. No. 4389; the Second International Agreement, 1960, CMND. No. 1759, (U.K.T.S. No. 45 of 1962 ); and the International Olive Oil Agreement, 1956, as amended by the Protocol of April 3, 1958, 336 U.N.T.S. 177. The short-term International Coffee Agreement, discussed in the text infra at 335-39, first entered into force October 1959; and was extended by its Board of Directors for additional one-year periods by Res. No. II of June II, I960; Res. No. 26 of September 27, I96I; and Res. No. 39 of October 4,1962 . It terminated upon the entry into force of the long-term International Coffee Agreement, 1962, on July $I$, 1963. The text has not been published in any standard compilation. The quota provisions of the Sugar Agreement were only effective for the first three years of its five year term, and since they failed of renegotiation and lapsed in $196 \mathrm{r}$, that agreement is not as a practical matter presently operative. The Olive Oil Agreement will be renegotiated this summer. The United States is party to the Wheat, Sugar, and Coffee Agreements.

International Commodity Study Groups have been established covering almost a dozen commodities, including lead and zinc, citrus fruits, rubber, wool, grains, cotton, and cocoa. For a discussion of the work of such groups, see Nichols, The International Lead and Zinc Study Group, 42 DeP'T State BuLL. 758 (I960); Mellen, International Consultations on Rubber, 44 DEP'T STATE BuL.. 78 (I96I).

The Long-Term Cotton Textile Arrangement, which recently entered into force, has certain features in common with primary commodity agreements, but is concerned with manufactured rather than primary commodities and problems of market disruption from low-cost imports rather than general market instability and price decline. For text, see 46 DEP'T STATE Butl. (1962). The Narcotics Convention (T.S. 612, T.S. 863 , T.I.A.S. No. 167 I, and T.I.A.S. No. 2308) and the Treaty constituting the European Coal and Steel Community (26I U.N.T.S. 140) are also concerned with problems of particular commodities.

As is explained at length in other articles in this issue, primary commodity agreements are basically of three types: (I) export quota agreements, such as the Sugar and Coffee Agreements, which support prices by limiting the exports of each member; (2) multilateral contract agreements, such as the Wheat Agreement, in which prices are supported within an agreed range through an undertaking by exporters to sell given amounts to importers at not more than a specified ceiling price, and an undertaking by importers to buy given amounts from exporters at not less than a specified floor price; and (3) buffer stock agreements, such as the Tin Agreement, in which prices are supported within an agreed range through the operations of an international buffer stock organization which enters the market to buy or sell the commodity at specified floor and celing prices. Each type has its particular virtues and defects, and, in practice, particular agreements may combine features drawn from several of these types.

Among the many recent discussions of the nature and international significance of the special problems of primary producing countries, see, e.g., the International Economic Consultants, Inc., study cited supra note I; Butler, Trade and the Less Developed Areas, 4I ForEIGN AFraIrs 372 (1963); and Commodities in Search of Stability, The Economist, Jan. 12, 1963, p. 130. 
bananas, tea, and lead and zinc. Moreover, serious consideration is being given to the possible use of such agreements as a means of handling the troublesome problems of agricultural trade relations between the Common Market and other agriculturalproducing countries. Commodity agreements are thus likely to play an increasingly important role in the world economy, and the Coffee Agreement may well form a principal model in future commodity negotiations.

Third, international economic agreements in general, and commodity agreements in particular, have been sadly neglected by international lawyers, despite the fact that arrangements of this type cumulatively embody important experience in the area of international cooperation and regulation, and are in some cases unique experiments in developing techniques of international legal control.4 Thus, in entering into economic agreements (in contrast with political agreements), countries have frequently been willing to make some concessions as regards strict concepts of national sovereignty; for example, by consenting to the use of weighted voting to reflect differences in national stakes in the matter, and to continuous and detailed international intervention by an international organization into matters of hitherto solely national competence. A comprehensive study and analysis of this experience is long overdue.

Finally, the story of the negotiation of the Coffee Agreement may be of more general interest as illustrating the particular international mechanisms and procedures which are involved in bringing such an arrangement into being, and the practical problems, conflicting interests, and opposing tensions which shape its form and substance. The history of the Agreement may thus serve to give a more realistic sense of how an international agreement actually comes about.

This article will emphasize this last aspect in an attempt to show the development of the Coffee Agreement as an example of the complex and many-faceted process of international problem-solving. The text of the Agreement is summarized and commented on in an Appendix.

\section{I}

\section{The Coffer Problem}

The International Coffee Agreement of 1962 evolved out of international efforts to solve the problem of chronic price instability and persistent overproduction and price decline in the international coffee market. Because of the importance of coffee in world trade and the great significance of coffee exports to the economic and political stability of the producing countries, this problem assumed a particular urgency.

In order to better understand the nature of the Agreement and the various forces that forged it, it is necessary to have some grasp of the technical and economic

\footnotetext{
"For a survey of some of these economic agreements, and a discussion of their general features, see Hexner, Worldwide International Economic Institutions: A Factual Survey, 6I CoLus. L. Rzv, 354 (I96r).
} 
characteristics of coffee itself, and, more generally, of the workings of the international coffee economy. ${ }^{5}$ The facts given below were the parameters within which the negotiation of the Agreement proceeded and its substance was formed.

Coffee is a tree crop, the beans consisting of the cherry-like fruit of the tree, which is typically roasted and ground or processed into soluble form before sale to the consumer. It is grown commercially only in tropical regions. Consumer preferences and thus price may markedly differ as between the three major commercial varieties: (I) Brazils, grown only in Brazil; (2) milds, produced mainly in the rest of Latin America; and (3) robustas, which come principally from Central Africa.

A central factor in the inflexibility of the coffee problem is the long gestation period (i.e., the period from planting to bearing) and the long producing life of the coffee tree. A tree will take from three to five years to begin bearing, but will then bear productively for twenty-five to forty years. The principal costs of cultivation to the grower arise from the cost of purchasing and clearing land and planting trees, rather than in harvesting, and a crop will generally be harvested regardless of market price. The practical result of the combination of these technical and economic factors is to make coffee production relatively "inelastic" to short-run changes in price. That is, coffee marketings do not readily expand or contract over short periods even when prices vary dramatically.

Coffee ranks first among agricultural commodities in terms of importance in world trade, and is second only to petroleum among all primary commodities, with exports valued in excess of one and three-quarter billion dollars a year. Its great importance in international trade derives principally from the fact that most of the world's coffee is consumed in countries which do not produce it-that is, to which it must be exported. Commodities such as wheat, rice, sugar, oils and fats, and livestock are of greater over-all economic importance than coffee, but since most countries produce at least part of their own requirements of these products, import needs are less. Coffee is also a very important item in United States imports, amounting in $196 \mathrm{r}$ to about six and one-half per cent of U.S. total imports. In earlier years, due to higher coffee prices, this percentage was considerably greater.

Over thirty countries grow coffee as a major crop. In the coffee year 1962 (which by trade custom runs from October I961 to September 1962) production amounted to about $7 \mathrm{I}$ million bags (each bag weighing 60 kilograms or about $\mathrm{I}_{32}$ pounds). The principal areas of cultivation are in Latin America, in which fifteen of the twenty countries of that region grow coffee, and Central Africa, with Latin American production greatly predominant. The most important producers are Brazil, which is responsible for about half the world's production, and Colombia, which

\footnotetext{
'Recent comprehensive studies of the coffee problem include the Coffee Study Group's I0-volume survey, The Wortd Coffee Problem: Present Status of the Industry and Future Prospects (ig6o62); and the UN Food and Agriculture Organization's study, THE WORLD Coffer ECONONY (FAO Commodity Bulletin Ser. No. 33, Ig6r). See also Vernon D. Wickizer, The Wordd Coffee Economy (I943); and Vernon D. Wickizer, Coffee, TEA AND Cocon Pt. I (Coffee) (I95I). Most of the facts and statistics in this and the next section are drawn from these sources.
} 
produces about eleven per cent. The next most important producers-El Salvador, Guatemala, Mexico, Portugese Angola, and the Ivory Coast-are each responsible for only five per cent or less of world production.

Almost every country of the world imports some coffee. In 1962 total world exports amounted to about 45.3 million bags. ${ }^{\circ}$ By far the largest consumer is the United States, which accounts for half of world imports. Europe collectively accounts for another two-fifths of world imports, with Germany, France, and Italy in that order most important. Comparatively little coffee is consumed in Eastern Europe, Africa, the Near East, or Asia.

Artificial trade barriers in the form of tariffs, quotas, and internal taxes have an important influence on patterns of coffee trade and consumption. While the United States imposes almost no restrictions of these types on coffee, ${ }^{7}$ significant barriers in the form of high import duties, quantitative restrictions, and internal taxes exist in the countries of the European Economic Community (the Common Market). ${ }^{8}$ Of particular importance is the fact that under the Rome Treaty the newly independent African countries of the franc zone will have a special associated status. As the common external tariff progressively takes effect, coffee imports from these countries will have increasingly favored treatment as compared with coffee imports from Latin America, ${ }^{9}$ potentially resulting in a very substantial decline in Latin American exports to Europe. As will be seen, the Latin American demand for the removal of these restrictions was a principal issue in the negotiation of the Agreement.

The enormous significance of coffee to the economic and political life of the countries which produce it can hardly be exaggerated. Almost all of the producing countries are underdeveloped, single-crop economies, which rely heavily upon coffee

- More detailed figures of production and exports for the coffee year 196r-62 are (in millions of bags of 60 kilograms or about 132 pounds each):

$\begin{array}{lccc} & \text { Borld } & \text { Brazil } & \text { Colombia } \\ \text { Total Production } & 7 \mathrm{x} & 35(49 \%) & 7.8(11 \%) \\ \text { Exportable Production } & 58 & 28(48 \%) & 6.8(12 \%) \\ \text { Exports } & 45.3 & 16.1(36 \%) & 6.5(14 \%)\end{array}$

${ }^{7}$ Coffee is on the United States tariff Free List (71 Stat. 516 (1957), 72 Stat. 602, I9 U.S.C. \$ 1201, para. I654 (1958)). However, coffee substitutes and adulterants, and coffee essences are presently subject to a tariff of $3 \phi / \mathrm{lb}$. (72 Stat. 88, Ig U.S.C. $\$$ I0or, para. 776 (1958)), although legislation now pending before Congress (H.R. 4198, 88th Cong., Ist Sess. (1962)) would amend the Tariff Act to place soluble and instant coffee on the Free List. For special provisions concerning coffee imported into Puerto Rico, see 46 Stat. 696 (1930), as amended, 47 Stat. 158 (1932), I9 U.S.C. \$ 1319 (1958); 48 Stat. 1017 (1934) as amended, 49 Stat. 665 (1935), 19 U.S.C. § 1319a (1958).

${ }^{8}$ Total burdens on coffee (import duties and internal taxes) within the Common Market countries have been estimated to amount in some cases to as much as $200 \%$ of import value. See Hearings Before the Senate Comm. on Foreign Relations on International Coffee Agreement, 1962, Executive H, 87th Cong., 2d Sess. 48 ( $\mathrm{x}_{963}$ ) [hereinafter cited as Hearings]. In addition, coffee imports into France, for instance, are subject to quantitative restrictions favoring imports from franc-zone African countries, which receive in this protected market prices considerably higher than world prices.

${ }^{\circ}$ Under an agreement of association between the European Economic Community and the franc-zone African nations, coffee tariffs will gradually diminish and ultimately be inapplicable to these countries. This will give these countries substantially preferential treatment as compared with other coffee producers who will eventuaily pay a common external tariff of $9.6 \%$ (to which figure the originally planned CXT of $16 \%$ has been reduced under the terms of a recent agreement). 
exports for the foreign exchange they need to pay for imports for current consumption and particularly for economic development. Thus, more than twelve countries depend upon coffee exports for from thirty to eighty per cent of their foreign exchange earnings, and close to half of Brazilian and more than two-thirds of Colombian foreign exchange comes from coffee. ${ }^{10}$ Among Latin American producers generally, almost a quarter of their total export earnings are derived from this single product, and a one cent decline in coffee prices means a foreign-exchange loss to Latin America of about 45 million dollars a year. Moreover, in some of these countries, taxes derived from coffee production account for as much as twenty per cent of total Government revenues. Coffee is thus of central importance to the existence of many of these nations, and the repercussions of economic difficulties in the international coffee economy may profoundly affect every facet of their people's lives.

Coffee is in fact subject to several persistent and thus far intractable economic problems: (I) a problem of short-run market instability; and (2) a problem of longrun overproduction in terms of what the market will absorb at remunerative prices. In effect, because of certain inherent technical and economic characteristics of coffee, the free-market mechanism has been unable to adequately perform its traditional function of bringing supply and demand into equilibrium at reasonable prices for both producers and consumers.

The short-run problem of recurring market instability, as evidenced by sharp fluctuations in coffee prices, results essentially from so-called short-run "inelasticities" of supply and demand of coffee-the inability of supply and demand to respond quickly to price changes occurring over short periods. Thus, on the supply side, when circumstances such as the Korean conflict bring rapid upward movements in demand and price, rapid adjustment of production to meet this demand is precluded by the fact that coffee trees cannot be brought into production for a period of several years. Conversely, if demand and price fall because of such factors as an economic recession in a principal consuming country, producers cannot quickly reduce production. Similarly, on the demand side, consumption of coffee is relatively stable, expanding or contracting only gradually in response to sharp changes in supply and price brought about by short-run factors such as variations in crops due to changes in weather.

In addition to these difficulties, coffee producers are also subject to a so-called

${ }^{10}$ In the Hearings on the Agreement before the Senate Foreign Relations Committee, supra note 8, at 76, the State Department submitted the following list of percentages of certain countries' total export earnings attributable to coffee (based on $196 \mathrm{I}$ statistics except as otherwise noted):

$\begin{array}{llll}\text { Colombia } & 7 \mathrm{I} & \text { Togo (I959) } & 4 \mathrm{I} \\ \text { Guatemala } & 60 & \text { Angola (r960) } & 35 \\ \text { El Salvador } & 59 & \text { Uganda } & 34 \\ \text { Ethiopia } & 5 \mathrm{I} & \text { Kenya } & 3 \mathrm{I} \\ \text { Brazil } & 5 \mathrm{I} & \text { Nicaragua } & 27 \\ \text { Costa Rica } & 49 & \text { Cameroun } & 2 \mathrm{I} \\ \text { Ivory Coast } & 46 & \text { Malagasy } & 20 \\ \text { Haiti } & 4 \mathrm{I} & & \end{array}$


"seasonal marketing problems," resulting from the fact that a substantial part of world production is harvested at about the same time of the year (summer and early fall). Since a number of Latin American producers, particularly in Central America, do not have the storage facilities or financial resources to hold such crops for orderly distribution throughout the year, a great deal of this coffee tends to flood the market at the same time, resulting in sharp price drops, with price increases in non-harvest seasons. As a result of these various factors, coffee prices often vary greatly within and between years.

The long-run coffee problem is simply that coffee cultivation has consistently tended to outpace the normal growth of world consumption. The comparative ease of coffee cultivation, the many areas of the world suited to its production, and the high yields and returns possible for the successful grower per unit of area cultivated as compared with other tropical crops, have led to a rapid and continuing expansion of productive capacity-at first in Brazil, then throughout Latin America, and most recently in central Africa. On the other hand, consumption has grown quite slowly (about three to three and one-half per cent per annum), principally as a function of normal population growth and the gradual development of new markets.

Despite this disequilibrium, the traditional producers of Latin America have generally failed to adequately respond to these changed conditions-as, for instance, by cutting back production or attempting to shift resources into more economic uses. Instead, they have in some cases adopted national support policies (such as production and export subsidies and preferential tax treatment for coffee production) which tend to maintain or increase production, and which, in some countries, particularly in Brazil and Colombia, have resulted in the accumulation of enormous stocks, which further overhang the market and depress prices.

The situation in the period since World War II illustrates this pattern. Strong demand during the immediate post-war period, coupled with successive frosts in Brazil in the period $x 948$ to 1953 , brought about sharply rising prices, which in turn resulted in a great increase in plantings, particularly in Central Africa. By the early I950's, these new plantings had begun to come into production, and by I955 world exportable production had overtaken demand. Since that time, the situation of overproduction has worsened and prices have pursued an almost relentless decline. Between 1954 and 1962, the average wholesale price of a pound of coffee fell from about 79 cents to less than 35 cents, or by more than fifty per cent. Present estimates of exportable production during the coffee year $1962-63$ amount to about 53 million bags, whereas estimates of imports for consumption amount to only some 46 million bags; that is, only about eighty-six per cent of the $1962-63$ crop can hope to find buyers. By Ig62, world stocks in the amount of some 66 million bags had accumulated-enough to supply the world's needs for some 18 months; Brazil alone now holds stocks sufficient to supply the world for over a year.

Moreover, Latin American producers have been subject to two special difficulties 
in this period. First, prices of Latin American imports have risen relative to the prices of that region's exports, resulting in a shift of the "terms of trade" against it. Second, African producers have cut increasingly into Latin America's traditional share of the world market, aided by substantially lower prices, the increasing acceptability to consumers of robusta type coffees in blends, preferential arrangements with the Common Market countries, and the suitability of the robusta coffees in the growing field of soluble coffees.

By I962, every indication was that, in the absence of some solution such as that hoped for in the Coffee Agreement, the situation would get worse rather than better.

\section{Previous Attempts at Regulation}

The growth of international cooperation with respect to coffee is fairly typical of such developments in other areas in the international economic field. At first, each country attempts to deal with the problem on its own. However, since no one country is ordinarily in a position either to control the international market or to effectively insulate itself from it, these unilateral measures have only an indifferent degree of success, and there is a slowly growing realization that the problem cannot be successfully dealt with in this way. A considerable period may follow in which the countries concerned slowly grope towards bilateral and then multilateral solutions. The problem is discussed in various international meetings, study groups are formed, and tentative and often unsuccessful first experiments at international agreement are made. During this incubation period, problems are gradually defined, possibilities grasped, experience accumulated, and policies crystallized. Also, the principal government and industry officials concerned get to know their counterparts in other countries and to understand each other's views. Finally, the climate of international opinion in the field may at last be prepared for substantial innovation, and the stage set for an attempt at effective agreement.

In the case of coffee, the chronic difficulties of the world coffee situation have been under discussion for some sixty years. ${ }^{11}$ In the years prior to World War II, attempts to regulate the market were primarily made by Brazil alone, which at that time produced most of the world's coffee. Thus, for many years Brazil, under a series of so-called "valorization" plans, sought to stabilize the world coffee market by limiting its own exports and, where necessary, buying and accumulating stocks. Between I93I and I944, it destroyed some 78 million bags of coffee-more than a year's current world consumption-in an attempt to maintain prices. However, as coffee cultivation in other areas developed (partly as a result of the market situation brought about by Brazilian stabilization efforts), and Brazil's share in the world

\footnotetext{
${ }^{11}$ See generally, on the background of attempts at international coffee stabilization, Part VI of the Coffee Study Group's study, op. cit. supra note I, at I7-48; Vernon D. WICKIZER, THE WorLd Coffee Economy ch. Io (1943), and Vernon D. Wickizer, Coffee, TeA ANd COCOA 26 et seq. (195I).
} 
market-became somewhat less dominant, it became apparent that such unilateral efforts were becoming increasingly expensive and ineffective.

The first experience in international coffee regulation occurred in 1940, when the United States and fourteen Latin American countries entered into the InterAmerican Coffee Agreement. ${ }^{12}$ The Agreement established a quota system providing for a division of the United States market among Latin American producers and required the United States to limit imports from non-Member countries. However, the Agreement was primarily intended to deal with the particular wartime problem created for Latin American producers by the closing of European markets and to strengthen United States relations with that area during this period of crisis, rather than being designed to solve basic coffee problems. It lapsed soon after the end of the war. Nevertheless, the Agreement succeeded in substantially increasing coffee prices during the time it was in effect.

With the post-war boom in coffee demand and prices, belief in the need for international measures diminished. By 1954, however, the coffee problem had again become disturbing, and interest in some form of international action resumed. Thus, the 1954 meeting of the American Ministers of Finance and Economy, acting as the Inter-American Economic and Social Council of the Organization of American States, called upon that Council's Special Committee on Coffee to study the world coffee situation, and, if it seemed feasible, to propose cooperative measures that could limit fluctuations in coffee prices and maintain them within levels satisfactory to producers and consumers. The OAS Secretariat prepared a series of detailed studies for the Special Committee, including two proposals for an international agreement.

However, by 1954, the price situation had not yet deteriorated to the point where most producers were vitally concerned. Moreover, it was generally considered at that time that an effective agreement could not be negotiated within the framework of the OAS alone, since participation of the African producers and the European consumers was believed to be an essential ingredient of any scheme's success. Also, the United States at that time found the prospect of an international agreement on coffee both difficult to accept in principle and questionable from the standpoint of feasibility. The OAS proposals were therefore not pursued.

In I955 and 1956, pressures for international action again mounted as production expanded and prices fell even more. The huge coffee crop of 195758 , and the increasing conviction of the existence of a condition of chronic overproduction, brought the situation to a head. In an attempt to secure at least temporary relief from the strong downward drift of prices resulting from the heavy surplus, seven Latin American producers-Brazil, Colombia, Cost Rica, El Salvador, Guatemala, Mexico,

\footnotetext{
${ }^{22}$ The Agreement was signed in Washington on November 28, I940 and became effective April r6, 194I. The quota arrangements were terminated in 1945 and the Agreement expired in September 1948. For a discussion of its background, see Daniels, The Inter-American Coffee Agreement, 8 LAw \& ConteMP. Prob. 708 (1941). Legislation implementing the Agreement (the Act of April I1, 1941, 55 Stat. 133) is curiously enough still included in the U.S. Code (19 U.S.C. \$ $\$ 355$ and 1356 (1958)).
} 
and Nicaragua-met together in Mexico City in October I957 and concluded an emergency short-term Mexico City Agreement based. on an allocation of quarterly export quotas to each participating country. However, the Mexico City Agreement failed to curb exports effectively and, though the decline in coffee prices was temporarily mitigated, the process of erosion continued.

Meanwhile, the United States, which for a variety of reasons was becoming increasingly aware of and involved in the problems of the developing countries of Latin America and Africa, began to take a serious interest in the coffee problem. In I958, on the initiative of the United States, a Coffee Study Group comprised of over twenty producing and consuming countries was formed, with headquarters in Washington, D.C.

Initial meetings of the Coffee Study Group resulted in the recognition that there were essentially two types of problems the Group had to face: ( $I$ ) the immediate and emergency problem of rapidly declining prices; and (2) the underlying problem of long-run disequilibrium. The Group's efforts were therefore directed along these separate but interrelated lines.

In the summer of $195^{8}$, in order to provide an emergency stop-gap measure to permit time for fuller study of the coffee problem and its possible solution, fifteen of the Latin American producing countries negotiated and signed the Latin American Coffee Agreement. This Agreement, which took effect in October 1958, was based upon a system of export quotas whereby each producing country was to retain a specified percentage of its total exportable production.

Further study by the Coffee Study Group during 1959 resulted in proposals to replace the Latin American Coffee Agreement by a new and somewhat broader and more comprehensive short-term agreement. Negotiations in Washington culminated in the signature of the short-term International Coffee Agreement, which came into force in October I959 for a one-year period. The Agreement specified quotas for each participant based upon its choice of either: (I) ninety per cent of its exports in its best year 1949 to 1958 , or (2) for any country having less than two million bags of exportable production, eighty-eight per cent of its current estimate of exportable production. The limitation in the alternative was designed to make it unavailable to Brazil and Colombia. Exports to certain non-traditional markets of Eastern Europe, Africa, and Asia were to be excluded from quota calculations. The short-term Agreement broke new ground by including, for the first time, nonLatin American producers; in addition to the fifteen former members of the Latin American Coffee Agreement, France and Portugal signed the new short-term agreement on behalf of their respective African territories or overseas provinces. However, importing countries were still not represented.

In September 1960 , the short-term agreement was extended for an additional year, with an increased membership of twenty-eight producing countries representing about ninety per cent of world exports of coffee. As will be seen, this agreement 
was also subsequently extended in $196 \mathrm{x}$ and $\mathrm{x} 962$ in anticipation of the negotiation and entry into force of the new long-term International Coffee Agreement.

Despite the ambitious nature of the short-term agreement, its broad producer membership, and some success in arresting the continuing decline in prices, it had been early realized by the Coffee Study Group that any such limited arrangement was an inadequate solution to basic coffee problems. First, the total and individual quotas established by the agreement were set at unrealistically high levels in terms of estimated world consumption, and hence had little chance of exercising any meaningful stabilizing effect on declining prices. Second, even these inflated quotas were being violated by certain of the member countries; these violations were difficult to police or to control due both to the fact that importing countries were not members and to the lack of certain agreed definitions, which gave rise to misunderstandings and disagreements as to just what exports were chargeable to quotas. Third, the agreement did not attempt to deal with the root cause of the long-run coffee problem-overproduction-and was thus at best a temporary palliative.

The limited success of the short-term agreement reinforced the conviction of the principal members of the Coffee Study Group that an effective long-run solution to the coffee problem could be attained only through a truly global pact including both exporting and importing countries in its membership, establishing realistic quotas, and making some sort of attack on the basic problems of overproduction and underconsumption. This conclusion was reinforced by an exhaustive tenvolume study of all aspects of the coffee industry undertaken by the Coffee Study Group and issued in successive volumes during the period December 1960 through April Ig62. However, it was equally clear that such an agreement could not hope for success without the active participation of the world's major importer-the United States; and United States policy, despite the participation of that country in the work of the Coffee Study Group, had under the Eisenhower administration been generally opposed to international commodity agreements (though the United States had, for special reasons, joined the Sugar and Wheat Agreements). The possibilities for a new agreement thus hinged on whether the attitude of the United States would change in this respect.

The answer was given by President Kennedy in his "Alliance for Progress" speech of March 196r, in which he announced, among other things, that the United States was ready "to cooperate in a serious case-by-case examination of commodity market problems." 13 The basis for this new United States position was the clearer

\footnotetext{
${ }^{13}$ The speech was given March 13, 1961. The relevant excerpt in full is:

-...

"Fifth, the United States is ready to cooperate in serious case-by-case examinations of commodity market problems. Frequent violent changes in commodity prices seriously injure the economies of many Latin American nations, draining their resources and stultifying their growth. T'ogether we must find practical methods of bringing an end to this pattern." 44 DEP'T STATE Bull. 471, 473 (1961).

Though the previous Administration had also expressed its willingness to consider such agreements on a case-by-case basis, the tone and content of the President's statement, coupled with other pronouncements
} 
comprehension by the United States Government of the close relation between the situation of the international coffee market and general problems of economic and political stability and development in the coffee producing countries, the growing foreign relations interest of the United States in the effective solution of those problems, and the obvious connection between the stability of foreign exchange earnings of such countries and their external aid requirements.

The new commodity policy enunciated by President Kennedy led to a further intensive study of the coffee problem within the United States Government. In August I96I, at the Special Meeting of the OAS Inter-American Economic and Social Council in Punta del Este, Uruguay, the Chairman of the U.S. Delegation, Secretary of the Treasury Dillon, formally declared that the United States was "prepared to join a workable coffee agreement, to use its good offices to urge the participation of other consuming countries, and to help in the enforcement of export quotas through the use of import controls," and that when the Coffee Study Group met in September, "the United States would propose that a new agreement be drafted to achieve these ends."14

The forces were thus marshalled and the stage set for an attempt at a global solution to the coffee problem.

\section{III}

\section{Preparatory Work}

With the formal announcement at Punta del Este that the United States was willing to participate and, more important, to assume leadership in the preparation and negotiation of a new long-term agreement, events began to move swiftly. ${ }^{15}$

The first step was the unanimous adoption by the Punta del Este Conference of three resolutions dealing with different aspects of the coffee problem, one of which (Resolution C.I) set forth general principles for a long-term coffee agreement for further implementation by the Coffee Study Group. ${ }^{16}$

In September I96I, the Coffee Study Group, whose membership had by this time (largely as a result of increasing interest and participation by importing countries) increased to over thirty-four countries, agreed that a basis existed for a long-term agreement, and appointed a ten nation Coordinating and Drafting Committee,

by the new Administration, made it clear that a real change of policy was occurring. See United States Coffee Policy, Coffec Annual r96r, p. 59.

${ }^{16}$ The statement was given on August 7, 196r. The full text appears in 45 Dep'T State BuLL. $355,359-60$ (1961).

${ }^{15}$ For a general discussion of some of the preparatory work for the Conference, see Santos, The LongTerm Agreement, Coffee Annual x961, p. 51, and Wood, Background of the Long-Term Agreement, id. at 45 .

${ }^{10}$ Resolution C.2 concerned international regulatory measures and seasonal financing. Resolution C.3 appointed a committee to negotiate the elimination of restrictions on coffee consumption (this being directed primarily at Common Market restrictions). Title IV of the Charter of Punta del Este establishing the Alliance for Progress deals with the subject of "Basic Export Commodities"; paragraph 6 of chapter II of that Title specifically endorses commodity agreements as a means of solution of commodity problems. See 45 Dep't State Bull. 459, 469 (r96r). 
chaired by W. Michael Blumenthal of the United States, Deputy Assistant Secretary of State for Economic Affairs, to prepare a draft. The Coordinating and Drafting Committee in turn chose three representatives in a personal and expert capacity to actually prepare the instrument with the assistance of the Coffee Study Group Secretariat. At the same time, the members of the short-term agreement extended it for an additional year until October 1962. By December 1961, a first draft of a proposed longterm agreement had been prepared and distributed to the various members of the Coffee Study Group and to more than fifteen additional countries for comment.17

In March I962, the Coffee Study Group met to consider this December draft. The meeting generally agreed that a new long-term agreement should, like previous agreements, be based primarily on a system of export quotas; that total quotas should be realistic in terms of world consumption; that importers should be included and should play a substantial role in policing the quota system; that imports from nonmember producers should be limited; that increased consumption should be actively promoted; and that meaningful measures to control production and stocks were essential. On the other hand, the meeting revealed that particular exporting countries were prepared to argue that, due to special and unique circumstances, they should not be subject to as onerous and restrictive quotas as other countries; that there was no substantial agreement on the role of price provisions, if any, in the proposed agreement, and their relationship to quotas; and that the European countries were cool to the idea of including in any agreement provisions relating to the reduction or elimination of coffee taxes, quotas, and preferences. There was in fact a disturbing general unwillingness of the participants to engage in full discussion of a number of key issues which a negotiating conference would have to face.

Nevertheless, the March meeting of the Coffee Study Group concluded that the December draft was a reasonable basis for negotiation, and that the Group should formally request the Secretary General of the United Nations to convoke a formal international conference in June or July of 1962 to negotiate a new long-term agreement. The Group also established a twelve nation Pre-Conference Coordinating Committee to continue discussions in the hope of broadening areas of agreement, to send missions to confer with interested countries and groups of countries, and, where possible, to further develop the December draft. ${ }^{18}$

The Coffee Study Group's request was referred by the United Nations Secretary General to the Interim Coordinating Committee for International Commodity Arrangements (ICCICA) of the United Nations Economic and Social Council

\footnotetext{
${ }^{17}$ The draft was Coffee Study Group Committee I Document CSG-I-30/6I(E) (Rev. 3). It was released to the public on December I7, I96I, and is summarized in Coffec Annual 1961, p. 63 .

${ }^{18}$ See Coffee Study Group release of March 28, 1962, "Conclusions Reached at the Coffee Study Group Meetings Concerning the Long-Term Agreement." The Pre-Conference Coordinating Committee consisted of six importers (United States, Canada, United Kingdom, France, Italy, and Sweden) and six exporters (Brazil, Colombia, Mexico, El Salvador, and two representatives of the Inter-African Coffec Organization). All members of the Coordinating and Drafting Committec were represented.
} 
(ECOSOC), which recommended that a conference should be convened. Thereupon, the Secretary General, under the terms of ECOSOC Resolution 296(XII), formally convoked a United Nations Coffee Conference to convene on July 9, I962 at United Nations Headquarters in New York City. ${ }^{19}$

There are several reasons why the Coffee Study Group requested United Nations sponsorship of the Conference. First, such a request was in accord both with the recognized role of the United Nations in such matters and with previous practice in the negotiation of commodity agreements. Second, such sponsorship would give the Conference a global character and the highest possible dignity. Finally, United Nations sponsorship would, as a practical matter, permit the Conference to avail itself of the advantages of a well-equipped meeting place and the know-how and experience of the United Nations Secretariat. The United Nations was, in turn, willing to accept such sponsorship as part of its regular responsibilities and usual functions in the international economic field-more particularly since the subject matter of the Conference was in accord with ECOSOC policies and efforts.

United Nations sponsorship had, however, certain implications for the Conference. In particular, it emphasized the necessity that the Conference comply with certain ECOSOC requirements (which in turn incorporated standards set forth in the draft Havana Charter for the proposed International Trade Organization) as regards both Conference procedures and any agreement it prepared. The most important of these requirements were that participation by all countries be permitted on equal terms and that the exporting countries as a group and the importing countries as a group have equal representation in any agreement. ${ }^{20}$

\footnotetext{
${ }^{10}$ ECOSOC Resolution 296 (XII) of August 2, 1950 authorizes the UN Secretary General to convene commodity conferences and provides general rules applicable to such action, including the general nature of the list of states to be invited and the preparation of a provisional agenda and rules of procedure. The resolution specifically permits separate representation at such a conference by dependent territories.

By ICCICA decision, invitations were sent to all I04 members of the United Nations; several nonmembers who had an interest in coffee; the members of the Coffee Study Group; the members of the UN Interim Commission of the International Trade Organization (ICITO); the members of UN Food and Agriculture Organization; and Rwanda and Burundi, which were only recently independent. Of course, most countries were members of several or all of these organizations. Observers were also invited from various UN specialized agencies, including the World Bank and the International Monetary Fund.

${ }^{20}$ By virtue of ECOSOC Resolution 30(IV) of March 28, x947 (U.N. Doc. No. E/403), UN commodity conferences are governed by the provisions of chapter VII (Inter-Governmental Commodity Arrangements) of the Draft Charter of the International Trade Organization of the United Nations, appended to the Report of the First Session of the Preparatory Committee of the UN Conference on Trade and Employment held at London, October 1946 (U.N. Doc. No. E/PC/T33). This is so even though the draft charter never entered into force.

The provisions of chapter VII of the Draft ITO Charter cover such matters as: the permissible objectives of commodity agreements (art. 47); the establishment of study groups (art. 48); the convening of commodity conferences to recommend the adoption of inter-governmental arrangements (art. 49); and circumstances governing the use of regulatory agreements (art. 52). In particular, articles $5 \mathrm{I}-55$ of chapter VII establish general principles which are to govern commodity arrangements. One of the most important of these is the requirement that there be equal participation of importing and exporting countries and an equal voice of each group in substantive issues (art. 5I). Other provisions provide that the governing body of each regulatory agreement should be a commodity council consisting of a representative of each of the participating countries (art. 54); and that such agreements be limited to a duration of five years, with a review of the provisions at intervals no greater than three years (art. 55). Paragraph
} 
Meanwhile, the preparatory work for the conference continued at both the international and national levels.

On the international level, the Pre-Conference Coordinating Committee arranged for a series of visits by the Secretary General of the Coffee Study Group, Dr. Joao Oliveira Santos, and by other informed experts, to a number of countries throughout the world to discuss preparations for the Conference, emphasize its importance, clarify the draft agreement, explain existing differences in viewpoint, urge highlevel representation, and stress the importance of responsible senior officials addressing themselves to the essential issues in order that each Government would have a thoroughly grounded position in advance of the Conference. The Pre-Conference Coordinating Committee also considered certain other questions, including the precise date at which the Conference was to meet, its general procedure and organization, and the thorny but extremely important question of the selection of a Conference Chairman. ${ }^{21}$

On the national level, many Governments were engaged in the enormous amount of preparatory work which precedes (or at least should precede) an international meeting of this importance. Delegations had to be chosen and their financing arranged; and positions and strategy debated, decided upon, and cleared at highpolicy levels. Moreover, even well in advance of the Conference, the business of negotiation and bargaining with other countries had to begin, for a formal international conference is only one stage in a long and complex process of intergovernmental persuasion, pressure, and accommodation that commences well before the conference convenes and may continue long after it closes.

The preparatory work undertaken by the United States Government was perhaps typical of that in a number of countries. First, in meetings of high government

4 of section V of chapter V of the Preparatory Committec's Report notes, in commentary on the Draft, that, subject to the principle of adequate representation of both exporting and importing groups, ". . . voting power may be distributed among countries according to the nature and extent of their individual in. terests."

ECOSOC Resolution 30 (IV) recommended that, pending the establishment of the ITO, Members of the UN adopt as 2 general guide in intergovernmental consultation or action with respect to commodity problems the principles laid down in Chapter VII. The Resolution also established the Interim Co. ordinating Committec for International Commodity Arrangements (ICCICA).

Under the provisions of paragraph (h) of article XX, and the interpretative note thereto appearing in Anner I of the General Agreement on Tariffs and Trade (GATT), discriminatory or restrictionist measures undertaken by any contracting party in pursuance of obligations under any inter-governmental commodity agreement conforming to the principles approved by ECOSOC in Resolution 30 (IV) of March 28, 1947 are not construed as violations of GATT.

${ }^{21}$ The selection of an able Chairman is vital to the success of any commodity conference. He should preferably be of international stature, impartial, not identified with any particular interest group, have leadership ability, and have some experience with commodity or other economic conferences. Another qualification for any chairman of a commodity conference is considerable physical stamina. In crucial moments of the Conference, the Chairman's personal moral force may be all that stands in the way of failure. The Chairman is usually paid by the Conference for his services.

The Chairman of the Coffee Conference, Mr. Mitchell W. Sharp, was a Canadian and had been Deputy Minister of Trade and Commerce of that country, resigning in 1958 to enter private industry and politics. He had participated in a number of commodity and trade conferences. He has recently been appointed Minister of Trade and Commerce of Canada. 
officials, a United States Delegation to the Coffee Conference was determined upon and appointed, and the necessary credentials prepared. Because of the importance and complexity of the Coffee Conference, an unusually large delegation was selected, consisting of eleven government officials from the Departments of State, Commerce, and Agriculture, and eight advisers from private industry. ${ }^{22} \mathrm{~W}$. Michael Blumenthal, Deputy Assistant Secretary of State for Economic Affairs, who had played a leading part in the work of the Coffee Study Group and had headed both its Committee $I$ and the Co-ordinating and Drafting Committee, was appointed Chairman of the U.S. Delegation.

Second, in a series of meetings both within the Government and between government officials and representatives of the National Coffee Association (the national trade association generally representative of all segments of the United States coffee industry), the basic position and objectives of the United States was determined as well as the strategy it would pursue in seeking to attain these objectives. This position was embodied in a formal confidential negotiating instruction issued to the Delegation. $^{23}$

Third, and concurrently with these other steps, lawyers in the State Department's Office of the Legal Adviser, with the assistance of lawyers in other agencies, were examining the draft agreement from a legal point of view, with particular emphasis on the obligations which the United States might be required to assume. In the course of this examination, it became clear that new legislation would be desirable before the United States joined any agreement along the lines of the one proposed,

\footnotetext{
22 The U.S. alternate Delegates were Mr. Henry Brodie and Mr. Paul E. Callanan, both of the State Department's Office of International Resources. Most of the private advisers were members of the National Coffec Association and of its Foreign Affairs Advisory Committee. A prominent part in the negotiations was played by Mr. Jerome Jacobson of International Economic Consultants, Inc., who served as a consultant on the Delegation under contract with the Agency for International Development.

28 Essentially, this United States position was as follows. The new long-term agreement should be based upon realistic export quotas which should not exceed the best available estimate of probable world demand. The United States should work hard for this objective, but should be careful not to inject itself in any way into the question of the allocation of country quotas within this global figure. The quota system should cover all types of coffee to all destinations for all purposes, and should not leave any loopholes. Thus, no "ex quota" shipments to "new markets" should be permitted. The agreement probably should not contain any specific price target, in view of the negotiating and administrative difficulties in attempting to establish specific price ranges for each type of coffec, as well as the political problems specific price targets would raise. Instead, prices should be generally left to the operation of market forces under the quota system. However, it should be made clear that the agreement is not intended to operate so as to bring about unwarranted price rises, and specific provisions to protect consumer countries in this respect should be included. The agreement should provide for the free movement of coffee on a non-discriminatory basis from all countries into consumption, and should seek to eliminate obstacles to trade and fiscal burdens which inhibit increasing consumption. Finally, the agreement should, as a key principle, recognize that overproduction is a root cause of the coffee problem, and provide some means for the orderly reduction of production and stocks and the encouragement of economic diversification in the producing areas. As will be seen, many, but not all, of these objectives were achieved.

For the general United States position as set forth by Mr. Blumenthal in a statement to the Conference on July 10, the day after its opening, see 47 Dep'T State Bull. 234 (I962). And as to general U.S. commodity policy at this time, see Blumenthal, International Commodity Problems, 46 Dep'T State BuLL. 997 (rg62).
} 
and, further, that it was impracticable to attempt to secure such legislation prior to the anticipated adjournment of Congress. ${ }^{24}$ For these and certain other reasons, it was decided that, if the United States should join a coffee agreement, it would do so through formal treaty procedures, with the advice and consent of the Senate and concurrent passage of the necessary implementing legislation, rather than by executive agreement. It was therefore apparent that the United States could not hope to become a party to any new agreement which might be negotiated until after the new Congress convened early in $\mathrm{rg}_{3}$.

Fourth, action was taken both through meetings with foreign embassy officials in Washington and through American embassies abroad to inform foreign governments of the importance which the United States Government attached to the success of the Conference, the need for thorough and timely preparation, and the necessity for each country to view the issues realistically and to be prepared to compromise if the Conference was to succeed. Individual meetings between State Department officers and key foreign officials were held to set forth the United States views and, where these corresponded to the views of the foreign government concerned, to establish plans for concerted action at the Conference. In addition, key congressional leaders were advised of the forthcoming negotiation and of the United States position and objectives.

Finally, in accordance with State Department procedures, permission was requested and received from the Secretary of State for the United States Delegation to enter into the formal negotiation of a coffee agreement at the forthcoming Conference. 25

With preparations and procedures such as these completed, the various delegations proceeded to New York for the Conference's opening.

IV

\section{The Conference}

The United Nations Coffee Conference convened on July 9, rg62 at United Nations Headquarters, New York City. Delegates from fifty-eight nations and

${ }^{26}$ Difficulties were apparent particularly with respect to the obligations contained in the Coffec Study Group draft requiring importing countries to limit imports from non-participants. Although $\$ 204$ of the Agricultural Act of 1956, 70 Stat. 200 (1956), as amended, 76 Stat. 104 (1962), 70 U.S.C.A. $\$ 854$ (Supp. I963), could be argued by its terms to permit such limitation, a study of the legislative history of that Act and the section in question suggested the advisability of securing new legislation to accomplish this objective.

Other legal questions concerned such matters as authority to require imports of coffee into the United States to be accompanied by certificates of origin, authority to grant immunity to the International Coffee Organization if it engaged in commercial coffee transactions, and the consistency of such a quota agreement with United States antitrust law and policy. Also relevant was the provision in Pub. L. No. 495, 82d Cong., 2d Sess. (July 10, 1952) which prohibits U.S. representatives to international organizations of which the United States was not then a member from, in the absence of specific authorization, "making any commitment requiring an appropriation of funds for a contribution by the United States in excess of $33 \frac{1}{3} 3$ per centum of the budget of such international organization."

${ }^{25}$ This was done in compliance with the Department's "Circular 175" procedure, more fully described in Bilder, The Office of the Legal Adviser: The State Department Lawyer and Foreign Affairs, 56 Axs. J. INT'L L. 633, 651-52 (1962). 
observers from thirteen other countries and three United Nations specialized agencies were present. ${ }^{26}$ In terms of the number of countries affected, the strength of the opposing interests, and the range of problems covered, the Conference was to constitute one of the most difficult economic negotiations attempted in recent years. Scheduled to finish by August I 7 , it was not to recess until August 25, and would not finally adjourn until September 28, more than two and one-half months after its commencement.

The express task of the Conference was to formulate a new long-term agreement. To achieve this objective, the fifty-eight countries represented had to resolve a number of difficult questions. The most important of these were the total level and division of quotas and the manner of their adjustment; the price objectives of the agreement and their relation to quotas; how to deal with the problem of production and stocks; the form of any new international organization to be established and the distribution of power within that organization; how to handle the problem of obstacles to trade and consumption; the treatment of non-participants; and the means by which the agreement was to be enforced.

As to each of these questions, and a number of others, there were strong differences of opinion and divisions of interest between fairly well-defined though overlapping groups of countries. The politics of the Conference consequently tended to be on the basis of "blocs."

The most important of these groups, and their principal interests and objectives, were the following:

(1) The Importers. While generally committed in the interest of international cooperation to attempting to assist exporting countries in achieving a workable solution to the coffee problem, the importers as a group were for the most part anxious to "do their duty" with the assumption of as few obligations as possible. In particular, they were under the political necessity of ensuring that their consuming public was not subjected to any marked increase in coffee prices, or their domestic trade to any more burdensome administrative regulations than were essential to the Agreement's operation.

(2) The Exporters. The exporters as a group wished to achieve a functioning agreement capable of at least stabilizing coffee prices at existing levels, and hopefully, of raising them. Within the group of exporters, however, interest in an agreement and ideas as to how general objectives were to be achieved differed greatly. Each foresaw that onerous burdens and restrictions would have to be assumed by the exporting countries, but each hoped to minimize the particular burden or restriction falling on it.

\footnotetext{
${ }^{20}$ The countries represented by delegations and observers are listed in UN Coffee Conference Press Release EC/2149 of August 25, I962. International organizations sending observers were the Food and Agriculture Organization, the International Bank for Reconstruction and Development, and the International Monetary Fund.
} 
(3) The Major Trading Countries. The principal importers and exporters, such as the United States, the Federal Republic of Germany, Brazil, Colombia, and the other nations represented on the Pre-Conference Coordinating Committee were particularly interested in achieving a workable agreement, but felt that their predominant importance in coffee matters should be clearly recognized both in the negotiation and the administration of the Agreement.

(4) The Smaller Trading Countries. The smaller traders were less certain of the value to them of an agreement controlled by the principal exporters and importers, and were afraid that their interests would be ignored in the process of negotiation and administration. Since under "one country-one vote" conference procedures their voting weight at the Conference was potentially greater than that of the principal trading countries, they intended to use this influence to the fullest in the negotiation to make sure that they fully participated in the making of Conference decisions and that their particular interests were protected.

(5) The Latin American Producers. The Latin American producers were being particularly hurt by declining prices and therefore had a special interest in achieving an agreement. However, they wanted an agreement which would tend to maintain their existing market position as against further encroachment by the African producers. Equally important, they wanted an agreement which would give them increased access to the European market by lessening or abolishing European internal taxes, quantitative restrictions, and preferences.

The Latin American group was divided into two subgroups:

(a) Brazil and Colombia, the two dominant world producers, both heavily dependent on coffee, had a special stake in an agreement. Brazil exerted a particular influence in the negotiations since it was clear that in any price war which might result from the possible failure of the Conference, it was in a position to create serious difficulties for other producers.

(b) The thirteen Latin American producers other than Brazil and Colombia were organized (together with Puerto Rico) into the Federation of Coffee Producers of America (Federation Cafelatera de America or FEDECAME). Many of these were heavily dependent on coffee for foreign exchange and considered an agreement to prevent further price erosion a necessity. Others were remaining uncommitted in order to see how the land lay and what advantage or disadvantage from their particular standpoint an agreement might entail. 
(6) The African Producers. The African producers were organized into the Inter-African Coffee Organization (IACO). These African producers had managed to secure a constantly increasing share of the world market. Moreover, the franc-zone African countries enjoyed special treatment in the Common Market countries. The IACO countries as a group were therefore anxious for flexibility in any agreement and fearful of inhibitions on what they considered would be their expanding share in world trade. Some of these countries were only newly independent, and still under the technical leadership of former colonial administrators, and were not sure that an agreement would actually serve their interests.

The African producers were also divided into several subgroups:

(a) The newly-independent countries of the Franc Zone, profiting particularly from French and potential European Common Market preferences;

(b) Tanganyika, and the United Kingdom exporting territories of Kenya and Uganda (since become independent); and

(c) Ethiopia, Nigeria, and certain other countries.

(7) The Common Market Countries. The importing countries of the European Economic Community, with France frequently acting as spokesman, were concerned, as all importers, in incurring as few obligations as possible. These countries were particularly interested in resisting any commitments to Latin American producers with regard to the reduction of taxes or quantitative restrictions, or any weakening of the preferred position of African coffees within the Common Market.

These blocs were not, of course, either clearly defined or unchanging. Instead, the interests of each country were expressed sometimes through one group, sometimes through another, and sometimes independently. The actual process of negotiation was thus a complex and constantly shifting pattern of coalition, pressure, and counter-pressure as each participant constantly weighed and balanced its various interests and bargaining positions-what it could afford to give up for what gainin the light of its overall objections and the shifting positions of other countries. How the ultimate balance would be struck was still to be seen.

\section{A. Procedure}

Because of the number of countries involved and the many issues to be resolved, the procedural aspects of an international conference constitute one of its most interesting and important features, and may largely determine its success or failure. ${ }^{27}$ The most complex and difficult negotiation can be brought to a successful conclusion

\footnotetext{
${ }^{97}$ For a comprehensive general discussion of the procedure of international conferences, see VLADIMTR D. Pastutiov, A Guide to the Practice of Internattonat Conferences (I945); and see Sir Ernest Macon Satow, A Guide to Diplomatic Practice 303-23 (4th ed. Sir Neville Bland, 1957).
} 
by careful organization, the entrusting of key questions to effective committees, and the wise selection of committee chairmen. The simplest negotiations as regards substantive problems may dissolve into chaos as a consequence of the lack of adequate procedural planning.

Fully recognizing this fact, the Pre-Conference Coordinating Committee had given considerable attention to the organization of the Conference. Even so, these arrangements proved less than completely effective in maintaining a constant momentum of decision by Conference committees. Major deadlocks were encountered which on several occasions brought the negotiations to a complete halt, and the Conference verged on disaster as its closing date approached with many vital issues unresolved.

The procedure and organization of the Coffee Conference were, with certain exceptions, typical of most commodity conferences. Both as of possible general interest in itself and in order to make clearer the ways in which the Coffee Conference diverged from accepted conference practice, the typical procedure of a United Nations commodity conference may be described in some detail.

A typical conference meets (either in plenary or in major committee) in a single large room, the various delegations being seated in alphabetical order in various tiers facing a central podium. On the podium are seated the chairman and the principal officials of the conference secretariat, including the conference executive secretary and the conference legal adviser (who are usually members of the staff of the United Nations Secretariat), and sometimes a special consultant on the technical matters of the conference. In the plenary and most committees, the conference secretariat provides simultaneous interpretation, keeps summaries of each meeting, and prepares, translates, and distributes all proposals and conference documents. ${ }^{28}$

The plenary of the conference, which is its formal embodiment as a meeting of official representatives of Governments, and which alone has authority to make decisions binding the conference, is convened by a temporary chairman, who is usually a representative of the Secretary General of the United Nations. Meetings of the plenary are generally open to the public. The provisional agenda and rules of procedure ${ }^{29}$ prepared prior to the conference by the Interim Coordinating Committee

${ }^{28}$ At the Coffee Conference, interpretation and translation were provided in English, French, Spanish, and Russian (all official UN working languages), and Portuguese. Because of the importance of Brazil and Portugal (due to Angola) in the Conference, Portuguese was used for the first time in a UN Conference as a working language. Since China was only an observer, it was decided that Chinese, which is a UN working language, would not be used.

The Conference Secretariat's summary records of meetings, together with the various proposals, all numbered according to a special system by committee and date of issuance, provide complete documentation of the Conference. However, since these Conference documents are not generally available, they are not referred to in this article.

The problem of prompt issuance and particularly translation of proposals and documents is an immense and formidable one for any conference secretariat. On a number of occasions in the Coffee Conference, sharp debates on what at first appeared to be substantive questions turned out to be the result of misunderstandings arising from errors in translation.

${ }^{20}$ The procedure of commodity conferences is in general fairly informal, and rules of procedure 
for International Commodity Arrangements are proposed and adopted. The conference then unanimously elects its chairman, who has usually been agreed upon beforehand by at least the principal governments represented and who serves in an individual rather than governmental capacity, and several vice-chairmen, who are usually heads of different delegations so chosen as to recognize important countries, different interest groups, and different geographic areas.

Next, the various committees are set up. A credentials committee is appointed and instructed to report back to the conference later in the session. The plenary also establishes the executive committee which, like a committee of the whole in a parliamentary body, is in fact the same representatives simply meeting under another name, and elects the chairman of the conference as the head of the executive committee. Finally, the plenary appoints a steering committee, consisting of the conference chairman and vice-chairmen and the chairmen of any principal committees established by the executive committee. The task of the steering committee is to guide and coordinate the work of the conference.

The conference plenary then adjourns into executive committee. From this time on, almost all of the principal business of the conference will be done in the meetings of the executive committee and its subordinate committees, which are closed to the public, and the conference plenary will meet in public session only to make formal decisions.

The executive committee commences its work by hearing a long and usually rather tedious series of delegation statements setting forth the views of each country on the various issues involved. These may represent anything from firm positions to simply opening bluffs in the negotiations. Simultaneously, the executive committee establishes a series of committees under it, to each of which is assigned a particular range of problems. When a draft agreement has been prepared prior to the conference, which is usually the case, it is typically accepted as the conference basis of discussion, and the committee assignments are made on the basis of an allocation of particular draft articles to each of these committees. ${ }^{30}$ These committees in turn ordinarily establish subcommittees or working groups to consider special problems. In addition, the executive committee usually establishes a legal and drafting committee of not more than five or six lawyers from various delegations,

are rarely invoked. Thus, commodity conferences typically conduct their business by a consensus taken by the chairman rather than by formal vote. Nevertheless, procedural questions may in certain instances become very important and on a few occasions formal votes-even roll call votes-may be demanded. Thus, the Coffee Conference was almost wholly tied up for several meetings in an extremely complex procedural situation arising out of the relatively insignificant question of what international organizations should be invited to attend the Conference in a consultative capacity. Originating in a proposal by Italy to invite the European Economic Community, the matter rapidly became one of politics and prestige, and a variety of other organizations were also proposed. After prolonged debate, great procedural confusion, and a number of votes (including a roll-call vote), the EEC, the OAS, and the Arab League were ultimately invited.

${ }^{\text {so }}$ There is inevitably a problem of overlapping jurisdiction between the various committees, and a need for the closest control by the Chairman and the Steering Committee in order to avoid duplication of work and confusion. 
who act largely in an expert and personal capacity, to provide legal and drafting services to the conference. ${ }^{31}$

As each committee reaches decisions on the matters entrusted to it, it reports these decisions back to the executive committee, most frequently in the form of new or revised draft articles proposed for inclusion in the agreement. Usually the reported articles are sent first to the legal and drafting committee, which may make various suggestions or drafting changes before sending the articles up to the executive committee. The executive committee hears and debates the various reports and may either accept them, instruct the relevant committee to make certain changes or study the matter further, or, more rarely, reach its own decision without returning the matter to committee. The actual proposed articles of the agreement usually receive three different "readings" during the conference-that is, the executive committee is given three chances to comment on each article (though the third reading is usually pro forma). These readings must commence fairly early in the conference if this procedure is to be completed.

When all the generally agreed articles have finally been adopted at third reading, the executive committee proceeds to adopt the text of the agreement as a whole. The legal and drafting committee then goes over this text to ensure consistency and clarity, and makes any necessary drafting changes. Finally, the conference meets in plenary session and formally adopts the agreement and any final act or other resolutions which may be proposed.

Turning now to the Coffee Conference itself, it will be seen that the Conference followed the initial procedures just described but was forced by lack of time to drastically vary the procedures with respect to readings and the final adoption of a text.

At the initial meeting of the Coffee Conference Plenary, the provisional agenda ${ }^{a 2}$

${ }^{31}$ The formal organization of a conference is, of course, only a partial picture of its actual working. Thus, in the Coffee Conference, the members of the Pre-Conference Commitice, the importers, IACO, and FEDECAME all held informal but regular meetings throughout the Conference, and particular problems would lead to informal caucuses of the various interest groups concerned. Much of the business of actual regotiation is done by delegations in the corridors, at lunches or dinners, or in hotel rooms. At the Coffee Conference, such informal meetings were particularly important due to the unwicldly size of Economic Committee II. The Conference Chairman may play a leading part in bringing about compromises during such informal meetings.

It might also be mentioned that a well-organized country delegation may be a key factor in its achieving of its objectives. The Brazilian delegation was outstanding in this respect. In contrast with many other delegations, some members of the Brazilian delegation were present at almost every conference meeting, regardless of its importance, and a continuous flow of reports and daily staff meetings kept the Chairman of the Brazilian delegation and all of its members constantly apprised of every development.

${ }^{32}$ The provisional agenda prepared by ICCICA for the Coffee Conference was as follows:

I. Opening of the Conference;

2. Adoption of Agenda;

3. Adoption of Rules of Procedure;

4. Election of Chairman and two Vice-Chairmen;

5. Credentials of representatives to the UN Coffee Conference, 1962, (a) appointment of Credentials Committee, (b) Report of the Credentials Committec;

6. Discussion of International Measures designed to meet the special difficulties which exist or are expected to arise concerning coffee; 
and rules of procedure were adopted, and a Credentials Committee appointed..$^{\mathbf{3 3}}$ As prearranged, Mr. Mitchell Sharp of Canada was unanimously elected Chairman, and the heads of delegation of Brazil, the United States, the Malagasy Republic, and Italy were elected First, Second, Third and Fourth Vice-Chairman, respectively. The Executive Committee was then established, which in turn, over the next week or so, established three major committees: (I) Economic Committee I, open to all countries, to which was assigned the subjects of production and stocks, obligations of importing countries, and financial and technical matters; (2) Economic Committee II, with a limited membership, to deal with the central questions of quotas, prices, and obstacles to trade and consumption; and (3) Administrative and Legal Committee III, open to all countries, to which was assigned the administrative, legal, and organizational provisions of the Agreement. It was generally accepted that the Coffee Study Group draft would constitute the basis of discussion. In addition, it soon became necessary to establish a special Statistical Committee of four experts acting in a personal capacity. Finally, though a Legal and Drafting Committee was in fact never formally established by the Executive Committee, a small Legal and Drafting Group eventually came into de facto existence. ${ }^{34}$

The key committee was, of course, Economic Committee II, with responsibility concerning questions of quotas, prices, and obstacles to trade. ${ }^{35}$ For this reason, the question of the composition of this committee became one of the first major problems of the Conference, and deserves some discussion.

On the one hand, it was clear and generally agreed that Economic Committee II simply could not deal with the complex issues it was assigned unless its membership was severely limited, and that the major producers and consumers most concerned

\footnotetext{
7. Establishment of an Executive Committee and other committees as required;

8. Preparation of an international agreement embodying international measures considered desirable;

9. Consideration and adoption of resolutions, Final Act, and so on.

10. Any other business.

${ }^{83}$ The Credentials Committee consisted of the United States, USSR, France, Mexico, and the Ivory Coast. The question of credentials may have strong political overtones due to differing Western-Soviet Bloc attitudes concerning the status of the Republic of China and certain Communist regimes. In commodity conferences, however, these questions are usually handled by each group making pro forma statements of their position for the record. At the Coffee Conference, the Republic of China was only an observer. The USSR and Cuba were represented by delegates, and Czechoslovakia, Poland, Bulgaria, and Rumania by observers. Political questions are generally not prominent in commodity conferences, which are primarily concerned with technical questions, although Cuba on a few occasions in the Coffee Conference raised political matters.

34 The membership of the Legal and Drafting Group, as originally established by the Legal Subcommittee of the Administrative and Legal Committee, consisted of the Conference Legal Adviser (Mr. Gurdon Wattles of the UN Legal Staff), and lawyers from the United States, the United Kingdom, German, Brazilian, Colombian, and Ethiopian delegations. The Legal Group worked principally in English.

${ }^{85}$ A large committee of this type made up of delegations is not the only way of handling the difficult and delicate task of quota allocation. Some commodity conferences (e.g., the UN Sugar Conferences) have used instead the device of entrusting the allocation of quotas to a small panel of particularly respected conference leaders or "wise-men," who hear each delegation's case in camera and impartially attempt to work out what they consider the fairest and most acceptable compromise. This system has much to recommend it.
} 
had to play a principal role in the making of key decisions as to these issues. For these reasons, the Pre-Conference Coordinating Committee had suggested that the membership of this committee be limited to twelve or fourteen major exporters and importers. On the other hand, it was clear that the decisions of the Committee were the basic ones which the Conference would make, would vitally affect the nature of any agreement drawn, and were thus of central importance to all of the participants in the Conference. The smaller producers in terms of volume argued that limited membership on Economic Committee II was inconsistent with the central concept of sovereign equality of states in such conferences, and would amount to a rigging of the Conference against the interests of smaller states. Each pointed out the vital importance of coffee in its economy and contended that no one but itself could adequately protect its interests.

The problem of the composition of Economic Committee II was finally resolved by an increase of the membership of the Committee to sixteen and the consequent inclusion of several of the smaller producers and consumers. ${ }^{36}$ In addition, there was a firm undertaking that all Conference participants would have an opportunity to state their positions before the full Committee, and a further understanding that the Committee would report weekly to the Executive Committee. Even so, over a week passed before Economic Committee II was established and began functioning, and the scars of this controversy never really healed. The complaint of the smaller states that their interests were being ignored persisted throughout the Conference and beyond, despite the fact that the need for restricted membership on Economic Committee II was generally conceded to be simply a fact of life of the Conference.

Aside from the problem of the composition of Economic Committee II, the most important procedural problem the Coffee Conference faced was that of completing its work within the time available. As is typical of many such conferences, the Conference proceeded at a leisurely pace for several weeks and then completed its work in a great rush. The first three weeks were devoted almost entirely to preliminary matters-the setting up of the various committees, statements by each delegation of its position, preliminary negotiation, and the collection of statistical material. During this period, the various delegations were holding their cards very close to their chests. It was not, in fact, until the fourth week of the Conference that the serious work of negotiation was really begun. The issues proved too difficult, however, to admit of quick solution. As the sixth week (the scheduled final week) of the Conference opened, many of the major problems were still unresolved, and less than half of the articles were reduced to even reasonably agreed language. There had as yet been no formal "readings" of any of the articles in Executive Committee.

\footnotetext{
${ }^{88}$ The problem was complicated by the fact that the Federal Republic of Germany originally attended the Conference only as an observer, but later, at the strong urging of many governments, changed its status to that of a formal participant. As the world's second largest consumer, it was an obvious candidate for a seat on Economic Committee II. The final membership of Economic Committec II was: ExportersBrazil, Colombia, Mexico, Costa Rica, El Salvador, Tanganyika, Portugal, Ivory Coast, and India; and Importers-United States, United Kingdom, France, Italy, Sweden, Australia, and Germany.
} 
Still hopeful of achieving an agreement, the Steering Committee decided to extend the Conference for several days. It was clear, however, that even with this extension, there would not be time to follow the usual procedure of readings in Executive Committee and approval of a final text. How was this problem to be handled?

A procedure was first proposed whereby the Conference would receive and approve the individual Committee reports without passing on the texts of individual articles, would instead refer these articles to the Legal Group for incorporation into the final text of an agreement, and would then recess. The text prepared by the Legal Committee would, upon its completion, be circulated to the participating Governments. In six weeks' to two-months' time, the Conference would reconvene for one or two days for approval of the Agreement prepared by the Legal Grouphopefully without change.

It became apparent upon further reflection, however, that any delicate compromises reached in the last weeks of negotiation would, under this proposed procedure, run a grave risk of becoming unstuck during the long interval which this plan contemplated prior to final approval. There seemed a dangerous possibility that some of the participants might use this period to seek better bargains, and that the Conference would as a result have to begin all over again when it reconvened. It was therefore necessary to find some procedural device which could be worked out in the remaining few days, yet have the result of effectively binding the participants to compromises reached during the present Conference session. The prospect that negotiations might have to be reopened at some future date was simply more than the tired delegates could face.

To accomplish this result, the Chairman, on August 20, proposed an alternative procedure whereby the Plenary of the Conference would actually adopt the texts of articles "for inclusion in the Agreement." This would fix the substance of the articles but not their form. These articles would then, as in the previous plan, be referred to the Legal Group which would be given broad discretion to make drafting changes, produce a final text, and distribute it to Governments. The Conference would reconvene in about a month only to approve or disapprove the Legal Group's work, but would not have authority to make substantive revisions in the Agreement, since the texts of the individual articles would already have been finally approved in Plenary. That is, the choice would be only to accept or reject the completed text. This procedure was ultimately adopted.

Agreement on the final procedure to be followed did not, however, mean that the Conference was yet in a position to utilize it. As the end of the seventh week approached, a consensus was still lacking on the most basic issues of the Agreementquotas, quota adjustment, prices, and voting procedure. In terms of Conference procedure, Economic Committee II had not yet submitted its report to the Executive Committee. Since many of the principal delegates had to leave to meet prior 
commitments and the United Nations facilities could not be made available any longer, it was clear that further extension of the Conference was impossible. On the afternoon of Thursday, August 23, the Chairman grimly announced that unless agreement on outstanding issues was reached in time for approval of the articles to begin on the following day and to be completed by Saturday, August 25, the Conference would adjourn sine die. This was the moment of truth. All that night the lights at the United Nations building remained on. A continuous series of meetings of the various groups, hallway conferences, and whispered negotiations occurred in a frantic effort to arrive at some acceptable compromise before the deadline. Finally, at about 5:30 a.m. on Friday, August 24, a final bargain on the quota issue was struck between the principal participants and the basis for the report of Economic Committee II was laid.

On Friday, August 24, only a few hours after the final compromise had been reached, a very weary Executive Committee approved the less controversial provisions of the Agreement in an article by article reading. By Saturday, August 25, the report of Economic Committee II had finally been prepared and distributed, and the quota provisions and remaining articles of the Agreement were formally agreed. The Conference then approved a series of final resolutions including one which: (I) requested the Legal and Drafting Group to arrange the provisions of the articles of the text in a clear order, ensure their coherence, and make necessary drafting changes, and (2) requested the Executive Secretary of the Conference to transmit these texts to the Governments and to arrange for the Conference to meet together for one day on September 28 to adopt a final resolution. ${ }^{37}$ After hearing a series of final statements, including attacks by a number of disgruntled delegations on the quotas set for them by Economic Committee II, the Conference recessed at II :30 p.m. on Saturday, August 25.

The recess of the Conference was but the beginning of the work of the Legal and Drafting Group. For four days, from Sunday, August 26 through Wednesday, August 29, the Drafting Group was in almost continuous day and night session redrafting and completely rearranging the text. On the afternoon of August 29, its revision was reviewed at an informal meeting attended by the Conference Chairman, members of the Conference Secretariat, and delegates from certain of the principal delegations. The final revised text was then prepared in the other official Conference languages by the Conference Secretariat and distributed to the participant Governments.

On September 28 the Conference reconvened. Following a long series of statements by various delegations, principally of a laudatory nature, the text as submitted was formally approved in Plenary and opened for signature. Twenty-three states signed the Agreement on that day.

\footnotetext{
87 The others resolutions related to "Improvement of the Operation of the Quota Provisions" and "Transitional Measures."
} 


\section{B. Issues}

Every international negotiating conference has to decide a great number of questions concerning the provisions to be incorporated in the final agreement. These questions may either be raised by the draft used as the basis of discussion, or raised by delegations during the negotiation as independent proposals.

Fortunately, very few of these questions are real issues in the sense of requiring actual negotiation. First, many proposals are on their face so clearly necessary or so generally acceptable as not to require real debate-only well-organized discussions indicating the common sense of their inclusion. In the case of the Coffee Conference, this was the situation with respect to such matters as the basic decisions to establish a quota system, to create an international coffee organization, and to have this organization collect information and make studies. Second, as to many other proposals, the opposition of important groups is so strong that it is apparent that such proposals cannot possibly be included in any agreement which is to have any wide measure of support or chance of success. Thus, it was quite clear from the beginning of the Coffee Conference that importers as a group would not accept any specific obligation to finance diversification schemes in exporting countries or to finance the carrying of surplus stocks, and that exporters as a group were unwilling to accept any specific commitments whereby their domestic production policies and stocks would be subject to international direction or control.

The negotiations thus centered about certain key issues on which there was fairly evenly-balanced controversy, but as to which compromise was possible. The most important of these issues were the following.

\section{Quotas.}

It had been generally accepted long before the Conference that any long-term coffee agreement should operate primarily through a system of export quotas. First, such a quota system would deal most directly with the basic problem of oversupply through control of the total flow of coffee onto the market. Second, the previous agreements had been primarily of this type and had justified the essential workability of such controls to their membership. There was consequently no debate on this basic question. ${ }^{38}$

A principal issue at the Conference, however, and the one on which it almost foundered, concerned the actual fixing and allocation of these quotas. Two problems were involved: (I) how large should the total overall quota (i.e., the total amount of exports of coffee allowed all Members) be, and how was this total quota to be adjusted; (2) what should be the relative share of each exporting country in this

\footnotetext{
${ }^{38}$ In early Coffec Study Group discussions, proposals were made that the Agreement include a buffer-stock arrangement and that stockpiled surpluses be placed under international control. However, in view of the great amount of surpluses and the enormous funds that would be required to finance a buffer-stock operation, that plan was not adopted. A multilateral contract scheme was never seriously considered, since an agreement of this nature could not effectively deal with basic coffee problems of constantly declining price and overproduction.
} 
total quota, and should these relative shares themselves be flexible and subject to adjustment? $^{39}$ These issues were primarily fought out between the various producer blocs.

As concerns the question of the total quota, all producers were in principle agreed that this quota should be "realistic" in the sense of not exceeding total demand at current prices. There was, however, a constant tension between two possible ways of arriving at this figure. On the one hand, it made sense to first arrive at such a "realistic" total figure on the basis of an economic analysis of probable total imports, and then to divide this total up between producing countries. On the other hand, there was a practical pressure to arrive at this figure by first setting individual quotas acceptable to each country and then totalling up these individual quotas to reach a global figure. Since the total of all individual quota desires would far exceed current or foreseeable demand, this latter method was virtually certain to produce an unrealistic total quota figure.

Projections as to the likely world demand for coffee over the next five years were produced by the Statistical Committee and were rather quickly agreed upon by Economic Committee II. Moreover, there was little disagreement that an International Coffee Council should be established and given the power to revise the level of total quotas yearly in response to changing estimates of world demand, and that this Council should also have special power to revise total quotas at any time if sharp fluctuations in price indicated market imbalance. However, despite agreement on these principles, the exact figure for total quotas was inevitably interrelated with the individual quota problem and had to await the resolution of that issue.

The real negotiations, therefore, centered about the question of "the division of the pie"-the share which each country was to have in any global quota, and the general basis on which such shares were to be calculated. Of course, each country argued for a system of allocation which would tend to increase its relative share; and many countries suggested that their case was unique and their needs greater, and that they should therefore be entitled to special treatment and a higher quota than other countries. Thus, the large established producers wished quotas to be based primarily upon available supply and historical shares of the market. Moreover, in order to further protect their existing market positions, they wished the respective shares of the various exporting countries to be firmly established in the agreement and not to be subject to later negotiation. The newer African producers, on the other hand, with developing productive capacity and a belief that the trend in consumer preferences would continue to favor their coffees, wished quotas established on the basis of potential production, with relative shares to be subject to flexible adjustment based upon the demand for different types of coffees as indi-

\footnotetext{
${ }^{30}$ These questions were complicated by the interrelation of quota decisions with possible decisions on the questions of price. Moreover, as a negotiating matter, the Latin American countries related the quota problem to the problem of obstacles to trade. There was considerable debate in Economic Committee II as to the order in which these questions should be taken up.
} 
cated by price or the degree to which quotas were actually utilized. ${ }^{40}$ The smaller countries wished the factor of economic dependence on coffee to be taken into account, or a special exemption for small producers from quota requirements. ${ }^{41}$ Countries with political dislocations such as the Congo wanted special account taken of their situation in this respect, particularly if their exports had declined because of such difficulties. A further complication was that, as a practical matter, each delegation felt it politically unacceptable to come back from the Conference with a quota smaller than it had received under the short-term agreement, or one that would not permit virtually all its present-and in some cases, its potentialproduction to be marketed.

Only late in the Conference were even the general principles for the final negotiation of quotas agreed upon. Under this scheme, each country's relative share in the total quota was to be based upon its average exportable production in its choice of either the two coffee years $196 \mathrm{I}-62$ and $\mathrm{x} 962-63$, or the four coffee years I959-60 through $1962-63$, the last year in each case of course being an estimate. This average figure was then to be reduced by a percentage varying roughly with the size of that country's production. ${ }^{42}$ That is, the largest producers, with the biggest stake in market stability, would sacrifice most by withholding a greater share of their exportable production. Actual quotas would also reflect special problems of particular exporters. The relative shares so established would be in general inflexible and would not be renegotiable for a period of three years, at which time the question of relative individual quotas would be re-examined. However, escape hatches would be provided in the form of waiver provisions, and more particularly in the form of withdrawal provisions permitting any country to get out of the Agreement quickly and easily if it found its interests seriously damaged under the actual operation of the quota scheme.

Generally speaking, this compromise favored the Latin American concept of

"The "quota reserve" system proposed by the IACO countries would have required the Council to withhold a certain proportion of the global quota for later allocation to various countries in accordance with market demand for coffees of particular types, as reflected by price increases.

12 As an extreme example, it was at one time proposed that only producers exporting more than $5 \%$ of world coffee exports be subject to quotas. This would, in effect, have subjected only Brazil and Colombia, and in some years the Ivory Coast and Angola, to the quota system.

${ }^{22}$ While the United States played a leading part in discussion of the level of total quotas, it attempted to avoid involvement in the negotiation of individual quotas. Nevertheless, difficult problems were created for the U.S. Delegation by the Conference's decision to use as the statistical basis for quota negotiations the estimates of exportable coffee production issued by the U.S. Department of Agriculture. These statistics were bitterly attacked by certain delegations, particularly Ethiopia and the Congo (Léopoldville), as a gross underestimate of their production. The U.S. Delegation took the position that the Department of Agriculture figures were published solely for the guidance of U.S. officials and the trade and were never intended to serve as a basis for quota negotiations, and that consequently the decision to use or not to use these statistics was entirely up to the Conference. A further problem arose from the fact that new Department of Agriculture statistics were scheduled to appear on September 27. There was consequently a tendency by certain of the exporters to favor delaying the quota negotiations until those statistics were out, in the hope that the new statistics would buttress their bargaining position. This problem was avoided when a corridor rumor appeared to the effect that the Department of Agriculture would probably postpone the issuance of new statistics for an undetermined period. 
rigidity rather than the African concept of considerable flexibility and "elastic quotas" responsive to "consumer preference." However, as a concession to the African position, a special Conference resolution (which was later adopted on August 25) was to provide that the Council shall make proposals to the Members not later than the third year of the Agreement to improve the operation of the quota provisions in relation to such objectives as the free operation of competitive forces and exercise of consumer freedom of choice as reflected by price movements.

Even with basic agreement on these principles, however, the actual decisions on country quotas were, as previously indicated, agreed to only in the very last minutes of the Conference, and were strongly affected by the varying negotiating skills and bargaining power of the different delegations. Moreover, in the final days, pressure from individual countries for increased individual allocations, and upward adjustments occurring in the last minute give-and-take, had the effect of in fact forcing the total quota figure beyond the projected figure for total world demand. In order to take care of this inflation of the total basic quota figure, the total annual quotas (i.e., permitted exports) for the first year of the Agreement's operation had therefore to be expressly limited to ninety-nine per cent of the total basic quotas.

Nor was final agreement on quota matters unanimous. A few countries were deeply disturbed by their failure to secure higher quotas, and the evening of Saturday, August 25, just before the Conference recess, was taken up by a scries of protests by Ethiopia, Guatemala, Honduras, Ecuador, Haiti, Nicaragua, and India on this score. Even at the meeting of September 28, when the Agreement was formally approved, Ethiopia, India, and Ecuador indicated that they might not sign the Agreement for this reason.

\section{Prices.}

Closely associated with the quota problem was that of price. Was the Agreement to contain specific price objectives as a guide to the establishment of quotas, and if so, what prices? There was very little open debate on this issue. The importers, while fully supporting measures to arrest the decline of prices, were opposed to marked price increases. A few exporters, on the other hand, wished to use the Agreement as an instrument to force prices up to the high levels prevailing in the immediate post-war years. Some importers had mixed interests. Thus, France, already committed to support the price of coffees produced by its former African territories at higher than market levels, proposed a system of "price indicators" so devised as to permit an escalation of price.

It quickly became apparent that it was politically impossible for the importing countries to accept any provisions which would actively seek sharp increases in prices. Moreover, it became more gradually clear that negotiation of specific figures and price spreads for the various types and grades of coffee was an impossible task in the time available, if it in fact could be done at all. It was decided, therefore, 
that rather than try to establish a detailed price system for each kind of coffee-all kinds are substitutable to some degree-prices would instead be left to be determined by the market indirectly through the adjustment of quotas, with the general objective in setting such quotas being that the level of prices not decline below the general level of prices in I962. In order to protect the interests of consumers against possible price manipulation by producers, the Council was given special authority to adjust quotas at any time by a simple majority vote, should sharp price fluctuations occur.

\section{Obstacles to trade.}

Aside from quotas, the most bitterly fought issue at the Conference concerned the demand by the Latin American producers that the countries of the European Economic Community undertake measures to reduce and remove internal taxes, quantitative restrictions, and trade preferences operating to the detriment of Latin American exports to that area. ${ }^{43}$

From the first days of the Conference, the Latin American producers insisted that an agreement was impossible in the absence of some effective commitment to this effect by the Common Market countries. The Latin American producers were generally supported by the United States, which favored the non-discriminatory treatment of all imports regardless of origin. The Common Market countries, on the other hand, took a firm position that they were unable and unwilling to negotiate such questions at the Conference. They argued that the Coffee Conference was not a proper forum for such matters and that in any event they simply did not have the authority individually or collectively to commit the European Economic Community to particular action in this regard. The Common Market countries were generally supported in their stand by the newly-independent African countries of the franc zone, who were the principal beneficiaries of existing and contemplated preferences.

\footnotetext{
¿s The strong feeling of the Latin American countries concerning Common Market preferences, quotas, and taxes was but one facet of the general and continuing concern of primary producing countries with this problem both in the coffee and other commodity areas. This concern is frequently manifested at international meetings. Thus, Resolution C.3 adopted by the Punta del Este Conference appointed a committee to negotiate the elimination of restrictions on coffee consumption. More generally, a GATT Declaration of November 13, I96I set forth certain guiding principles designed to reduce obstacles to exports of less developed nations. In June I962, a meeting of the Special GATT Group on Trade in Tropical Products in Geneva established a subgroup to study, on a commodity-by-commodity basis, the effect of preferential arrangements on such exports, and to develop alternative proposals. The Special GATT Group recommended that the International Coffee Agreement should include the principles of the GATT Declaration of November 13, $_{3}$ 196r.

Shortly after the Coffee Conference, on November 15, 1962, the United Nations Economic Committee overwhelmingly approved a thirty-five power resolution calling for an international conference on trade problems. This resolution included a clause asking the preparatory committee for the Conference to consider placing an item on the agenda entitled "Measures for the removal of tariff, non-tariff and other trade barriers arising from industrialized countries, whether individually or from economic groupings, which adversely affect the exports of developing countries and the expansion of international trade in general." N.Y. Times, November I6, 1962, p. I, col. 8; p. ro, col. 4 .
} 
For a considerable period, it appeared that the Conference would founder on this question alone, and at one point Brazil ceased active participation in Conference debates for several days in protest against the apparent unwillingness of the Common Market countries to grant concessions on this matter. Finally, in the sixth week of the Conference, following weeks of complex and behind-the-scenes negotiation (some of which occurred at high government levels), an acceptable compromise was reached. Under the language ultimately agreed to, importing countries were not to be firmly committed to specific action to remove such obstacles. However, the principle was generally recognized that practices such as preferences and high internal taxes are undesirable and should be eliminated, and a procedure was established whereby measures to remove such obstacles are to be reviewed by the International Coffee Council.44

\section{New Markets.}

Another major question was how inclusive the quota system should be, and, more specifically, whether shipments to the so-called "new markets" of Eastern Europe, Africa, and the Far East whose consumption of coffee was traditionally low, either because of low income or low preference for coffee, should be excluded from this system.

A number of producers argued for such an exclusion on the grounds that exports to these areas could not substantially affect the market situation, and that unhampered competition in the development of these markets would lead to their more rapid expansion. On the other hand, broad exemptions of this nature were opposed by the United States and various other importers, who pointed out that exports which had been permitted to such destinations under the short-term agreement, had in fact (particularly in the case of East Germany and Bulgaria) been re-exported to traditional markets and had constituted a principal quota-evading device under that agreement. They argued that such an exemption would similarly weaken the new Agreement.

The pressure for some sort of recognition of the "new market" principle proved too strong, however, to be defeated, and a carefully controlled exception was provided for exports to such areas. It was agreed that "new market" countries should be specifically named, and that total permissible exports to these destinations should be established by the Council. Such exports were to be closely watched;

\footnotetext{
"An interesting aspect of this debate was the strong objection expressed by the USSR and Cuba to language in the finally agreed text of what eventually became article 47(3) listing "operations of Government import monopolies and official purchasing agencies" among the "measures which may to a greater or lesser extent hinder the increase in consumption of coffee." Despite strong assurances by the Conference Chairman and various delegations that this language was not intended to have any political overtones, the USSR and Cuban delegates asserted that the phrase in question amounted to an attack on Socialistic economic systems, which conduct their foreign trade through State monopolies, and that retention of this language would constitute a barrier to signature. Both the USSR and Cuba in fact signed the Agreement, but in both cases with a declaration that "the above mentioned reference cannot be interpreted as applicable to the foreign trade monopoly" of their country.
} 
re-exports from such markets were to be prohibited; and, in the event of re-export to traditional markets, the offending "new market" country would be stricken from the list of permissible "ex quota" markets.

\section{Obligations of Importing Countries.}

A principal change envisioned by the new agreement as contrasted with the short-term agreement was the participation of importing countries. Their role was intended to be largely that of helping to police the arrangement and to ensure compliance with the quota provisions. While it was clear from the start that the obligations of importers would be fewer and less far-reaching than those of exporters, considerable debate occurred as to the exact nature and extent of these obligations. In particular, questions arose whether importing countries should be required to restrict imports from countries not parties to the Agreement and to prohibit importation of coffee from Members when shipments were not accompanied by particular documentation. On the one hand, the exporting countries, supported by the United States and a few other importers, maintained that strict controls of this nature were necessary if the Agreement was to work. On the other hand, a number of European importing countries argued that restrictions on imports from such outside countries would be inconsistent with their present efforts to liberalize trade, and that detailed documentation requirements would create unnecessary and burdensome difficulties.

The issue was finally resolved in favor of rather strict importer obligations. Until the Agreement's membership represented ninety-five per cent of world exports, imports from outside countries were to be restricted to average quantities from such countries imported in certain base periods. Moreover, within ninety days after the Agreement came into effect, importers were not to permit entry of coffee without prescribed certificates designed to identify the coffee's country of origin for quota purposes.

\section{Voting.}

How were countries to share in the decisions of the new coffee organization? The principle was accepted, as it had been in previous commodity agreements, that exporters and importers should vote as separate groups and that a system of weighted voting should be adopted under which countries would in general have voting power in proportion to their relative shares in exports and imports. ${ }^{45}$ In the particular

\footnotetext{
"For examples of weighted voting in international economic agreements other than commodity agreements, see article $\mathrm{V}(3)$ of the International Bank Articles and article XII(5) of the International Monetary Fund Articles. An interesting discussion of why Governments are willing to accept weighted voting in international economic agreements is contained in Metzger, Settlement of International Disputes by NonJudicial Methods, 48 AM. J. INT'L L. 408, 4I6-I7 (I954), which deserves quotation at length:

"[The rationale for weighted voting] is simple, sound, and has not been seriously questioned. Nations have acknowledged the justice of a system which allocates voting influence on the basis of relative investment .... They appreciate that where concrete economic cooperation among nations of unequal wealth and power takes the form of unequal commitments which, in turn, correspond closely to their inequalities of wealth or trade in the subject-matter of the particular agreement, it is both logical and
} 
case of coffee, however, the relative shares of Brazil in exports (almost forty per cent) and of the United States in imports (almost fifty-two per cent) were very large. Should these two countries be permitted a veto power over the decisions of the new organization, and would such large voting power on their part not leave most of the less important trading countries, as a practical matter, virtually powerless?

Early in the Conference, it became evident that there was a strong general feeling that the voting power of the United States and of Brazil should be limited to some degree. This was manifested first through proposals that an absolute limit be placed on the number or proportion of votes which any one country could exercise. It was expressed secondly through proposals that a certain proportion of the total votes be distributed equally between countries as "basic votes," and that only the remainder of the total votes be distributed on a weighted voting basis, thus diluting the weighted voting influence of the larger countries. Third, it was urged that simple majority votes rather than two-thirds majority votes (which could be vetoed by the larger countries) apply to many decisions. Finally, there were suggestions that no single Member should be permitted to block action which all the other Members wished to take-i.e., that there be no possibility of a veto by the larger countries. Brazil and the United States recognized the concern of the other countries with their large voting influence, but were reluctant to give up an effective veto over decisions of a nature conceded to be of enormous importance to them in terms of their proportionate interests and stakes in world trade in coffee.

In the final days of the Conference, an acceptable compromise was worked out. The United States agreed that no single country should exercise more than forty per cent of the votes within its importing or exporting group, though both the United States and Brazil rejected suggestions for a thirty per cent limitation. Moreover, it was settled that of the rooo votes to be exercised within each group, up to $1_{50}$ were to be allocated equally to the members of that group on a "basic vote" basis.

\footnotetext{
inescapable that those nations whose risks are greatest expect to influence those risks to a maximum degree, through influencing decisions within the framework of the rights and obligations set out in the agreement itself.

"Moreover, nations with smaller voting influence (as a consequence of their smaller commitments) appear to be willing to participate in this system because certain other key circumstances usually prevail: (I) the commitments themselves, in terms of money or materials, are measurable in concrete terms, so that extraneous considerations of 'prestige,' 'face,' etc., are palpably irrclevant; (2) the framework of rights and obligations established in the agreements is usually a tight one; the decisions to be taken by weighted voting, while important, must be within this framework; as a consequence, the risk that unforseen obligations will thereby be imposed on those nations with small votes is minimized; (3) the agreements are either for relatively short periods... or contain simple withdrawal provisions. . . . Consequently, the damage which can be done to small nations is greatly minimized, since they can withdraw from the agreements immediately or within a very short time if they consider that their interests are being given short shrift. This circumstance, which is well known to the nations with larger voting infuence, acts as a brake upon any inclination they might have to wield their voting power in an unrestrained manner, for they might find that, if they did so, the agreements would become unworkable because of withdrawals by dissatisfied nations with smaller voting power, or that their renewal on that basis would be impossible to negotiate."
} 
Only the remaining votes after this distribution were to be allocated on a weighted voting basis. As to the votes necessary for important decisions, it was agreed that while two-thirds distributed majorities (i.e., two-thirds of the votes in the exporters group and importers group counted separately) would be required for most important decisions, less stringent requirements would apply to Council action to meet sharp price fluctuations. Finally, a formula was devised whereby no single country could alone veto a proposal; instead, the negative votes of at least two countries would be required. Thus, the United States would have to find the support of at least one other country if it wished to defeat a proposal.

\section{Powers of the Executive Board.}

Another issue concerned the scope of authority to be granted the fourteenmember Executive Board. Some countries felt that if the Agreement was to operate effectively, the Executive Board, as the Organization's only continuing body, must necessarily be granted broad powers, particularly with respect to adjustment of quotas. They argued that only such a continuing and workable body could act with the promptness required for decisions in this area. Other countries were strongly opposed to a broad grant of powers to the Board. They felt that important decisions affecting all the Members should be kept solely in the Council, on which all Members were represented, instead of being delegated to the Board, which could not truly represent all the Members. In back of this attitude, there was probably a fear by some countries that the Board, if granted broad powers, might attempt detailed interference into the market.

This issue was eventually decided in terms of a reservation of almost all significant decisions to the Council, and a resulting strong restriction on the authority of the Board.

\section{Membership.}

One of the most troublesome conceptual and drafting problems which the Conference faced concerned the question of membership, and particularly whether membership in the Organization should be restricted to sovereign states (which alone had capacity to become parties to an international agreement), or whether provision should also be made for separate participation by dependent territories and by groups of states which might form economically-linked producing units.

There was little debate over the proposition that countries where the metropolitan territory was a net importer, but which had one or more dependent territories which were important exporters, should be permitted to join the Organization separately as regards their metropolitan territories and such dependent territories. ${ }^{46}$ More controversial, however, was the question whether groups of exporters which might

\footnotetext{
so The principle of separate representation of exporting dependent territories in commodity agreements was accepted in chapter VI of the Draft ITO Charter. See also article III of the Second International Tin Agreement and article XXVI(5)(c) of GATT.
} 
wish to participate jointly should be permitted to do so, and if so, under what conditions and with what rights.

The possibility of group membership was of particular importance to the IACO countries. First, a number of these countries (e.g., some of the franc-zone nations) did in fact function economically as a group. Second, the African countries wished to retain in so far as possible a group influence as a counter-balance to the influence of the Latin American countries. In addition, group membership offered the possibility of greater flexibility in quotas, since a single group quota could potentially be allocated among the group's members according to circumstances and needs.

It was finally agreed that separate membership in the Organization by exporting groups of countries would be permitted. However, in the case of group membership, the individual members of the group would be required to assume individual as well as joint responsibility for the performance of their obligations under the Agreement, and the group would have to establish to the satisfaction of the Council that it was in fact economically interdependent in coffee matters. Evidence that such countries had (I) previously been recognized as a group, or (2) shared a common and coordinated commercial and economic policy in relation to coffee and a coordinated monetary and financial policy, would be acceptable for this purpose.

\section{Headquarters.}

Where was the new International Coffee Organization to be situated? Latin American countries argued strongly for either New York or Washington on the basis that the United States was the world's principal importer and the center of the world coffee market. European and African countries argued equally strongly for London on the grounds that it was more geographically convenient to the largest number of countries, and was already the seat of the Wheat, Sugar, and Tin Councils. An unspoken consideration behind the debate was a feeling that proximity of the Headquarters to one or more of the principal blocs of Members would have some bearing on the influence those countries were able to exert in the new Organization. Ultimately, on the final day of the Conference, the Latin American countries were outvoted on this issue and London was selected. The United States and the United Kingdom both abstained in the vote.

\section{Io. Entry into Force.}

How great a participation should be required before the new Agreement came into effect? Since the effectiveness of the Agreement would clearly depend not only upon membership by a large number of countries, but also on membership by countries accounting for a considerable proportion of the world's export and import trade, it was decided to establish requirements based on both of these criteria. The major Latin American producers, supported by the United States, were anxious that the Agreement and its system of quota controls should enter into force as soon 
as possible, and thus favored a relatively low percentage of ratifications for this purpose. The European importing countries, on the other hand, were concerned about their obligation to restrict imports from non-joiners and argued that the Agreement should not take effect until it had been accepted by a relatively high proportion of countries. The figures eventually agreed upon-twenty exporting countries and ten importing countries accounting respectively for at least eighty per cent of world exports and imports in I96I-represented a compromise between these two positions. In order to get the Agreement into force more quickly, it was also decided that a procedure should be provided for provisional entry into force based upon the deposit of notifications of intent to seek ratification, as well as upon the deposit of formal instruments of ratification.

\section{The Lawyer's Role in the Conference: The Legal and Drafting Group}

As it developed, lawyers played an important role in the negotiation and drafting of the Coffee Agreement. At first, however, during the preparation of the Coffee Study Group draft and in the early stages of the negotiation, their potential contribution was largely ignored. This circumstance may justify a brief digression in this article on the work of lawyers at such international commodity (or other) conferences, and the services which they can most usefully perform.

Generally speaking, only the largest and most important delegations to international conferences on economic or political matters (as opposed to legal matters) will include legal advisers, although frequently many delegates have legal backgrounds. At the Coffee Conference, the delegations of the United States, United Kingdom, Germany, Brazil, Colombia, Ethiopia, and a few other countries specifically included lawyers. In addition, the United Nations Secretariat usually furnishes a member of its legal staff as Conference Legal Adviser, and did so at the Coffee Conference. While the Legal Adviser's views are of course not binding on the Conference, they generally have great weight.

The first responsibility of an attorney assigned to a delegation is, of course, to assist his delegation in its work. His legal skills will be utilized in such matters as the interpretation of instructions, the drafting of proposals and statements, the analysis of proposals made by other countries (particularly those which might create difficulties under his own country's law and practice), and the handling of legal problems of a general nature which arise in the course of the negotiations. ${ }^{47}$ Moreover, the Delegation lawyer does his share in the lobbying activities which are an indispensable part of any negotiation. He is usually also responsible for any legal matters concerning the Conference which arise before or after the actual negotiations,

\footnotetext{
"One such question involved a proposal under which Members would have been allowed to pay their dues to the Organization in "kind," i.e., in coffee, which the Organization would then sell. Aside from the danger of the possible use of "payments in kind" as a device to circumvent quotas, such commercial dealings by the Organization might have raised serious problems as to whether blanket privileges and immunities should be extended to it.
} 
such as helping in the preparation of a negotiating position consistent with national law, securing any necessary negotiating authority or credentials, assisting in the technical aspects of signature and ratification, and preparing and bringing into effect any necessary implementing legislation or regulations.

Perhaps the most interesting function of a lawyer in connection with such a Conference, however, is in relation to the preparation of the draft used as a basis of discussion and in his work as a member of the Conference Legal and Drafting Committee.

Since the principal objective of such international conferences as the Coffee Conference is the preparation of an international agreement, which is often an extremely complex legal instrument, legal experts must obviously play a role. Thus, at a minimum, Foreign Office lawyers must take major responsibility for the preparation of the "final clauses" (which relate to the method by which Governments become party to the Agreement, its entry into force, duration, territorial application, amendment, and the like), and must carefully go over the final text of the Agreement to ensure its substantive and drafting consistency. What is not so well recognized, however, is the great contribution that lawyers can make more generally towards the success of a conference's work, particularly in clarifying the basic issues and focusing debate on real rather than verbal questions.

The lawyer's particular usefulness arises from the fact that a multilateral conference has no practical procedural alternative but to discuss the matters before it on the basis of some sort of written text. If this text is clear and unambiguous and presents the substantive issues squarely, the conference can, as it should, devote all of its time to discussion and resolution of the substantive policy questions involved. On the other hand, if the conference has before it draft articles which are vague and ambiguous, or which conceal the substantive issues in drafting problems, the participants will inevitably spend a great amount of time debating what are essentially drafting issues in an attempt to arrive at a new and useful basis of discussion. At the extreme, the inertia inherent in a draft accepted as a basis of discussion may cause a premature hardening of attitudes; and the conference may be "frozen into" a poorly prepared draft and never be able to escape the limitations and confusions it embodies.

Unfortunately, a tendency to view the lawyer as a "mere technician," coupled perhaps with a certain fear that he will improperly intrude himself into the discussion of substantive issues, can still be found at some international conferences, and the substantial benefits that adequate legal services can provide in easing and speeding conference work are not always utilized. This point can perhaps be made more clear by contrasting a somewhat idealized drafting procedure with the procedure actually utilized at the Coffee Conference.

In principle, legal experts should be both represented in the preparations for an international conference and present at every stage of its actual work. It is of great 
importance that the pre-conference draft which is to constitute the basis of discussion should be carefully gone over by a team of legal experts to make sure that its provisions are well drafted, internally consistent, and clear. Ideally, the decisions facing the conference respecting each draft article should be indicated in notes to the preparatory draft, or in draft alternative texts.

Upon the convening of the conference, one of its first acts should be the appointment of a legal and drafting committee of not more than five members, made up of legal experts from the various delegations (serving primarily in an individual capacity rather than as country representatives) and the conference legal adviser. This Committee should serve directly under the plenary and the conference chairman. It should be constantly available to render legal and drafting assistance to any of the other conference committees, which should be encouraged to seek such assistance, since frequently the lawyer's special experience in international organizational techniques may be of considerable help on substantive problems. If possible, the legal committee should attempt to organize itself in such manner that one of its members is present at each meeting of every major committee, so that it will be informed as to the background and intent of the draft articles sent to it.

Each draft article should automatically pass through the legal committee on its way to the executive committee, and the legal committee should be authorized to refer such articles back to the reporting committee for clarification if necessary. The legal committee should review the complete text of the agreement before its final submission to the plenary for final approval.

The history of the preparatory work for the Coffee Conference and of the work of its Legal and Drafting Group indicates that the procedure at the Coffee Conference fell far short of this ideal, and illustrates some of the typical problems that lawyers may face.

First, the Coffee Study Group draft, which formed the Conference basis of discussion, was drafted without the assistance of Foreign Office legal experts. Whatever the draft's merits otherwise, it was, from a strictly legal point of view, ambiguous and out of line with accepted international drafting practice in a number of respects. ${ }^{18}$ As a consequence, the Legal Group had to spend more than a week of its short-lived existence reworking considerable sections of the draft, including all of the "final clauses" and the provisions on membership and certificates of origin. In the meantime, the Conference had no alternative but to base its discussion on the

${ }^{48}$ In a number of cases where the Coffee Study Group draft could usefully have simply picked up standard language already used and accepted in other commodity agreements, it did not do so. This was particularly true as regards the "final clauses."

This suggests the need for the preparation of a useful and practical handbook on the drafting of final clauses for multilateral (and perhaps also bilateral) agreements. The "Handbook of Final Clauses" prepared by the Treaty Section of the Office of Legal Affairs of the UN Secretariat (ST/LEG/6 of August 5, I957) is solely a compilation of clauses from existing agreements, and does not attempt to establish standard forms or discuss the drafting problems involved. Hopefully, such a handbook could simplify drafting problems without obscuring the obvious need to re-think such clauses in the light of the substance of the particular agreement involved. 
text of the Coffee Study Group's draft, and an inordinate amount of time was wasted in the various committees on what were essentially drafting rather than substantive matters. ${ }^{49}$ More confusion occurred when, late in the Conference, the Legal Group's revisions of substantial portions of the Coffee Study Group's draft were finally placed before the various committees.

Second, the Legal Group was not established until August $\mathrm{r}$, more than three weeks after the Conference was convened. ${ }^{50}$ Particularly in view of the difficulties just referred to, this left too little time for the group to do its work. Moreover, rather than being set up directly under the Plenary and the Conference Chairman, the Legal Group was established as a subgroup of the Legal Subcommittee of the Administrative and Legal Committee, which was in turn under the Executive Committee. In fact, the Group could not and did not utilize this long "chain of command." Also, the Group's original terms of reference were strictly limited to the technical preparation of the "final clauses," though in practice, its work necessarily had to expand quickly to embrace a review of all the articles of the Agreement. In general, the limited time available to the Group and the great pressure it was under seriously interfered with its ability to follow the work of the Conference as a whole, and hampered the effectiveness of its operations.

Third, the procedure which the Conference was forced to adopt respecting its approval of the final text placed a considerable burden of responsibility upon the Legal Group. In place of the Conference's original, unduly narrow view of the importance of legal services to its work, which had resulted in the ignoring of lawyers in the preparation of the draft and a delay in the establishment of the Legal Group until the fourth week of the proceedings, the Conference under its final procedure gave the Legal Group, if anything, excessive powers of discretion. Thus, the Resolution of August 25 in effect referred to the Legal Group a group of hastily approved articles, many of which had never passed through the Group for drafting changes ${ }^{51}$ or for a study of their mutual consistency. The Group was directed to forge these articles into a finished and coherent final text, without in theory changing any of the substantive understandings which they reflected. In practice, of course, the Legal Group had in many cases no choice but to make substantial changes in these often ambiguous draft articles. This was done, however, with the frightening realization that any such changes were subject to attack at the

\footnotetext{
${ }^{40}$ Perhaps the most important rule of procedure in international conference-as in any such meetingis never to attempt to draft in large committees. In view of the number of people concerned, the diverse views represented, and the diffculties arising from different languages and imprecise interpretation, the task is simply impossible.

${ }^{50}$ While an able member of the UN Secretariat's Office of Legal Adviser was present as Conference Legal Adviser, his duties-which included attendance at all Executive Committee meetings and the keeping of careful records of decisions bearing on the texts of the various articles-were simply too arduous to permit him to perform single-handedly more than limited drafting functions.

52 Thus, due to limitations of time, the quota articles included in the final report of Economic Committee II were approved by the Executive Committee without thorough examination or revision by the Legal Group.
} 
final September 28 meeting of the Conference, and might well furnish a basis for the Conference failing to adopt the Agreement. While adding to the interest and excitement of any legal committee's work, such a delicate situation is certainly one any conference will do well to avoid.

In the case of the Coffee Conference, this story had a happy ending, but things might have worked out less well; at the extreme, these difficulties could possibly have resulted in failure by the Conference to produce an effective instrument. ${ }^{62}$ The experience of the Coffee Conference emphasizes the urgent need for international lawyers to make a determined effort to bring home to Governments and to delegations to international conferences an understanding of the absolute necessity and the real advantages of an adequate and timely use of legal expertise in both the preparation and the work of such meetings.

\section{$\mathrm{V}$}

\section{The Afternath}

Despite many difficulties, the Coffee Conference was thus successful in its task of negotiating and adopting the text of a new Agreement. From the viewpoint of either the economist or lawyer, the International Coffee Agreement, I962 (which is summarized and commented on in the Appendix) is a less than perfect instrument. Substantively, all of the history and hopes, conflicts, and compromises which combined to mold it have resulted in a weaker and less comprehensive arrangement than some might have desired. Technically, the haste and at times confusion which accompanied its drafting have left their mark. Nevertheless, in terms of the practical problems and negotiating realities which the Conference faced, the Agreement represents a remarkable achievement.

The opening for signature of the Agreement did not, however, mean that the work of the negotiators had yet finished. Though the form of the Agreement had been fashioned, a great deal remained (and still remains) to be done in order to bring it to life and guide it in its first steps.

By November 30 , 1962 , the last day permitted for signature, fifty-four countries had signed the Agreement. ${ }^{53}$ Since thirty-two of these were exporting countries representing more than ninety-five per cent world exports and twenty-two were importing countries representing more than ninety-four per cent of world imports, ratification or notification by these countries would suffice to bring the Agreement into force. The most important and pressing piece of business for signatory delega-

\footnotetext{
Es Luckily, the various members of the Legal and Drafting Group worked well together and were able to reach decisions quickly. Had this not been so, it seems in retrospect unlikely that the Legal Group could have done an acceptable job in the time available.

${ }^{53}$ The fifty-four Governments signing the Coffee Agreement by November 30, 1962 are listed in UN Press Release L/r04I of December 4, 1962. Evidence of general world-wide support for the Agreement was given on November 22, 1962, when the UN General Assembly's Economic and Financial Committee approved 82 to I a resolution strongly endorsing the Agreement. N.Y. Times, Nov. 23, 1962, p. 45, col. 3 .
} 
tions was therefore the obtaining of these ratifications or notifications as rapidly as possible. Immediately upon returning from the Conference, most of these delegations bent their efforts to putting the appropriate machinery into action for securing the necessary approval by their Governments.

Action by the United States was, of course, a sine qua non to entry into force of the Agreement. The process of United States Government action in this respect was consequently of particular significance and may serve to illustrate some of the procedures and problems involved. As will be seen, this process was to prove more difficult and time-consuming than originally anticipated, and even at the time of this writing legislative action has not yet been completed.

As previously indicated, the Administration had decided well in advance of the Conference that, if an acceptable Coffee Agreement was prepared, it would be submitted to the Senate as a treaty, rather than being acted upon as an executive agreement. This decision was based upon various factors, including the importance of the Agreement, the desirability of obtaining implementing legislation prior to formal ratification, and the precedents established by ratification of both the Wheat and Sugar agreements as treaties. However, since Congress was scheduled to adjourn only shortly after the Conference itself adjourned, it was apparent that it would be impossible to obtain Senate approval to ratification and congressional enactment of implementing legislation prior to the convening of the Eighty-eighth Congress in January, Ig63. Nevertheless, in order to demonstrate the interest of the United States in the Agreement and to permit study of its provisions by the staff of the Senate Foreign Relations Committee in the interim, the necessary papers were quickly prepared and the Agreement formally submitted by the President to the Senate on October 4, 1962, less than a week after it had been signed. ${ }^{54}$ During the congressional recess, draft legislation to implement the Agreement was prepared by the Department of State with the assistance of the other Government agencies concerned, and was first informally and then formally cleared within the Executive branch. At the same time, preliminary inter-agency meetings were held to explore the practical and administrative problems which might arise as regards the carrying out of United States obligations under the Agreement.

In January Ig63, the Eighty-eighth Congress convened, with an Administration request before it for rapid action on the Coffee Agreement. However, hearings were not held by the Senate Committee on Foreign Relations until March I2, 1963. The hearings indicated strong support for ratification by both the Administration and the National Coffee Association, and little apparent public opposition. ${ }^{65}$ On May

st These documents consisted of: (x) a Report to the President from the Acting Secretary of State explaining the Agreement; (2) a certified copy of the Agreement; and (3) a Message from the President to the Senate transmitting the Agreement and the Report. They are published in Senate Document "Executive H," 87th Cong., 2d Sess. (1962).

${ }^{\mathrm{s}}$ See Hearings Before the Senate Committee on Foreign Relations, on Executive H, 87th Cong., $2 d$ Sess., The International Coffee Agreement, 1962, 88th Cong., 1st Sess. (1963). Principal witnesses appearing in support of the Agreement were the Hon. George G. McGhee, Under Secretary of State for 
I3, the Senate Committee Report on the Agreement was issued, reporting it favorably without reservation and strongly recommending that the Senate give its advice and consent to ratification. ${ }^{56}$ The Committee noted, however, its concern as to the United States embarking on such a program for a period as long as the five year term of the Agreement with no provision for legislative review in the meantime. It therefore recommended that Congress limit the initial validity of the implementing legislation to a period of two years, so as to ensure congressional review of the Agreement after some experience had been accumulated regarding its operations. Moreover, the Report was not unanimous. Presaging possible difficulties in Senate floor debate, a minority view filed by three of the seventeen members of the Committee urged that the Senate reject the Agreement, on the grounds that it would create burdens for the American consumer without substantially contributing to the long-term solution of the coffee problem.

On May 20, the resolution of ratification was taken up by the Senate, discussion on the question continuing through May 21. ${ }^{57}$ It was by this time apparent, and was confirmed in the opening debate, that opposition of unexpected strength had developed, based principally on the fear that the Agreement would cause a rise in coffee prices, doubt as to the efficacy of the Agreement to solve the coffee problem, and concern that Senate approval might be interpreted as sanctioning proposals to enter into such commodity agreements on a broad scale. Since a Senate resolution advising and consenting to ratification of a treaty constitutionally requires concurrence by two-thirds of the senators present, opposition by even a substantial minority was a most serious development, and it was evident that only strong advocacy on the Senate floor and Administration assurances could avoid real trouble. Accordingly, a special effort was made by leading senators to point out the need for the Agreement, to emphasize the protection it afforded United States interests, and to stress the unfavorable foreign relations impact which would be created by

Political Affairs, testifying for the Administration, and John F. McKiernan, President of the National Coffec Association, testifying on behalf of that organization.

Questions asked of the witnesses by the members of the Senate Committee evidenced their principal concern with the potential effect of the Agreement on American consumers, particularly as regards any possible price increases, and clearly brought out the fact that U.S. participation in the Agreement was regarded by the Administration and the Committee as justifiable primarily in terms of foreign policy interests rather than in terms of particular consumer benefits. The Committee also showed an interest in levels both of import duties and taxes and export duties and taxes in other countries; the quota given Cuba under the Agreement; the procedures for U.S. withdrawal if this became desirable; the relationship of the Agreement to the U.S. Aid program; and the possibility of the Council's extending the Agreement beyond the five-year basic period. As to this last point, the Committee Chairman expressed his feeling that the Administration should not vote in the Council for extension of the treaty beyond a five-year period without permitting the Congress to first examine the Agreement's operation and give its concurrence to such an extension.

${ }^{\text {so }}$ See Senate Executive Report No. $I$ on the International Coffee Agreement, 1962, 88th Cong., Ist Sess. $(1963)$.

57 The Senate debate appears in the Congressional Record for May 20 and 2I. See Iog Cong. Rzc. 8512-29 and 8551-56 (daily ed. May 20, I963), and I09 Cong. Rec. 8618-25 and A3200-or (daily ed. May 2I, Ig63). 
its rejection by the Senate. To support this effort, Acting Secretary of State Ball, on May 20, wrote Senator Humphrey a letter making clear the Administration's view that the Agreement was not self-executing and that implementing legislation would be required to meet certain United States obligations, and expressing the Administration's concurrence in the Foreign Relations Committee's proposal that the implementing legislation be limited to a period of about two years, thus permitting congressional review of the question of continued United States participation in the Agreement at the end of that period. ${ }^{58}$ Presumably, if Congress failed to renew this authority, the United States would withdraw from the Agreement under the provisions of article 68, which permits such withdrawal on ninety days' notice.

These combined efforts, the State Department's assurances, and, in particular, Senate recognition of the important foreign relations aspect of ratification of the Agreement, were undoubtedly significant in obtaining increased support for the Agreement. ${ }^{59}$ When on the afternoon of May 21 the yeas and nays were ordered and the roll called, the resolution of ratification was carried by a vote of 69 to 20 , with Ir Senators not voting. The motion to notify the President of Senate advice and consent to ratification was carried without objection.

With Senate advice and consent to ratification secured, the next step prerequisite to ratification was the obtaining of implementing legislation. During the week following the Senate action, the draft International Coffee Agreement Act prepared by the Administration and incorporating the Senate Committee's suggestion for a two-year limitation was submitted to both houses of Congress and then brought to the attention of the Senate Committee on Finance and the House Committee on Ways and Means. ${ }^{60}$ By this time, however, it appeared that final action by Congress

58 This letter is set forth at 109 CoNG. REc. 8619 (daily ed. May 21, 1963). The letter suggested that the expiry date be September 30,1965 , in order to coincide with the closing date fixed in article 72 of the Agreement for its overall review by the Council.

${ }^{50}$ That these assurances had a substantial effect is apparent from Senator Dirksen's statement supporting the Agreement (109 Cong. Rxc. 8624 (daily ed. May 21, 1963)). As to the importance placed on the foreign relations aspect of ratification, see, for instance, Senator Mansfield's statement that the Agreement "is absolutely indispensable to our country's good relations with the Latin American Republics" (rog Cong. Rec. 8624 (daily ed. May 21, r963)) and Senator Fulbright's statement that "The initial repercussions of [any rejection of the Agreement by the Senate] will be political in nature and they will be severe, particularly in Latin America" (rog Cong. REc. 8619 (daily ed. May 21, 1963)).

"The draft bill has the short title, the "International Coffee Agreement Act of I963." Its key provision is section 2 which provides:

"Sec. 2. On or after the entry into force of the International Coffee Agreement, 1962, and for such period prior to September 30,1965 as the Agreement remains in effect, the President is authorized, in order to carry out the provisions of that Agrcement, to:

(I) regulate the entry of coffee for consumption or withdrawal of coffee from warchouse for consumption, including (a) the limitation of entry or withdrawal from warehouse of coffec imported from countries which are not Members of the International Coffee Organization, and (b) the prohibition of entry of any shipment from any Member of the International Coffec Organization of coffee which is not accompanied by a certificate of origin or a certificate of re-export, issued by a qualified agency in such form as required under the Agreement;

(2) require that every export or re-export of coffee from the United States shall be accompanied by a certificate of origin or a certificate of re-export, issued by a qualified agency of the United States designated by him, in such form as required under the Agreement; 
on the bill might possibly be delayed until the late summer or even the late fall of I963.

This delay raised new and extremely serious problems. It was considered of great importance that the new Agreement become actually operative by the beginning of the coffee year commencing October $x, 1963$. For arrangements to be made, it was necessary for the International Coffee Council to meet during the summer, and preparations were already underway for sessions in London commencing in July. However, the Council could obviously not meet until the Agreement entered provisionally or definitively into force, and this could not occur without some form of United States action-either formal ratification or deposit of an instrument notifying the Secretary General of its intent to ratify. Each of these alternatives raised legal and policy problems.

After careful consideration of the alternatives, and despite the fact that the Administration would have preferred to defer any action until the implementing legislation had been secured, it was decided that the only practicable choice was for the United States to deposit an instrument of notification. This instrument was drafted so as to clearly reflect the actual situation-that, while Senate approval had been secured for ratification, the implementing legislation necessary for the United States to fully carry out commitments under the Agreement had not yet been obtained. On June 24,1963 , this United States notification of intention to ratify the Coffee Agreement was deposited with the Secretary General of the United Nations. ${ }^{61}$

The deposit of this notification by the United States brought the Agreement with-

(3) require the keeping of such records, statistics and other information, and the rendering of such reports relating to the importation, distribution, and consumption of coffee as he may from time to time prescribe;

(4) take such other action, and issue and enforce such rules and regulations, as he may consider necessary or appropriate in order to implement the obligations of the United States under the Agreement."

For comparison with legislation implementing other commodity agreements, see $\$ 4 \mathrm{II}$ of the Sugar Act of I948, as amended, 70 Stat. 221 (1956), 7 U.S.C. \$ II6I (1958), and the International Wheat Agreement of 1949 , as amended, 70 Stat. 966 (I956), 7 U.S.C. $\$$ r64r (I958).

To meet United States commitments, it will also be necessary for the President to designate the International Coffee Organization under the International Organizations Immunities Act, 59 Stat. 669 (1945), 22 U.S.C. $\$ 288$ et seq. (1958). The Coffee Study Group is so designated. Exec. Order No. 10943, May 19, 196r, 26 Fed. Reg. 44r9 (196r).

${ }^{\prime}$ See Dep't of State Press Release No. 329, June 24, 1963. The notification included the following paragraph:

"The Secretary of State wishes to note that the United States Senate has already given its advice and consent to ratification of the Agreement. However, under the Constitution of the United States, it will be necessary to secure domestic legislation in order to enable the United States to carry out certain of the obligations under the Agreement. In particular, it will be necessary for the United States Government to receive specific authorization from the Congress to require certificates of origin on all coffee imported into the United States, and to prohibit or limit imports of coffee from non-member countries. The necessary Iegislation has been introduced into both the Senate and the House of Representatives of the United States, and it is anticipated that the authority will be available at or shortly after the commencement of the coming coffee year. Until the implementing legislation has been enacted, the United States does not assume any of the obligations for which such legislation is necessary."

This formulation might have raised interesting legal questions for the depositary. 
in a hair's breadth of provisional entry into force. Since with this notification, twenty-five exporting countries representing 88.7 per cent of coffee exports and eleven importing countries representing 78.5 per cent of world imports had deposited either ratifications or notifications, additional action by only one other importing country representing as little as 1.5 per cent of imports would be sufficient to meet the requirements. On July I, I963, Sweden deposited its instrument of ratification, lifting the required importer percentage over the top and bringing the Agreement provisionally into force among the thirty-seven countries which had deposited instruments by that date. ${ }^{62}$ While ratifications instead of notifications meeting the requirements of article 64 are still necessary prior to the end of 1963 in order to bring the Agreement definitively into force, since July $I$ it has been a going concern.

Aside from the important task of bringing the Agreement into force, there were also a great number of other things which had to be done. Measures were required to take care of the transition from the old short-term agreement to the new one, to lay the groundwork for the establishment of the Organization, and to prepare for the first meeting of the International Coffee Council. A resolution adopted by the Coffee Conference on August 25, 1962 recommended that the members of the shortterm Agreement, in so far as possible, put into effect the quotas of the new Agreement pending its coming to force, and that they otherwise take charge of matters during the transitional period. Pursuant to this request, the Consultative Committee of the short-term agreement was reorganized to ensure that the transition from the old to the new Agreement should be as smooth as possible and that there should be no dislocation of markets in the interim. In addition, the Secretariat of the shortterm agreement, in consultation with the United Nations Secretariat, made arrangements for the first meeting of the Council, including the provision of a meeting place and staff, and preparation of a draft agenda. ${ }^{63}$

With the convening of the first session of the Council, currently scheduled for July 29 in London, the work of the Conference will be finally completed, and the future of the Agreement will rest in the hands of the Organization it has created. In practice, negotiations have already commenced both within and without the Consultative Committee regarding the many major issues which the first Council meeting will face, ${ }^{64}$ and the inevitable process of bargaining and compromise which

${ }^{62}$ The member countries are listed in the UN Circular Note of July 9, 1963 , announcing the provisional entry into force of the Agreement. The Circular Note also indicates whether the countries deposited ratifications or notifications. Only fourteen of the twenty-five exporting countries and four of the twelve importing countries deposited ratifications. The rest deposited notifications. Sce also UN Press Release $\mathrm{L} / \mathrm{IOg}_{4}$ of July $\mathrm{I}, \mathrm{Ig} 63$. A number of other countries have subsequently deposited instruments of ratification or notification.

${ }^{68}$ The suecess of the Conference also temporarily revived interest in a U.S.-endorsed proposal for a Seasonal Marketing Fund to provide a regional stabilization system for Mexico and the Central American producers. The Fund would have operated within the general provisions of the Coffee Agreement, and would have been financed through a substantial loan from the U.S. Government. See as to background 46 Dep't State BuLI. I78 (1962).

o\& These issues will concern, inter alia, the determination of the size of the world quota for the next coffee year and its distribution between members, production and stock controls, new markets, price 
began long before the Conference and will continue throughout the life of the Agreement is again underway.

\section{VI}

\section{Prospects and Problems}

There is much to be said both in criticism and in defense of international commodity agreements in general, ${ }^{65}$ and the Coffee Agreement in particular. As a practical matter, an attempt to negotiate a long-term coffee agreement was probably a political and economic necessity. Once negotiated, it is important that the Agreement succeed rather than fail. Whether the Coffee Agreement will in fact prove successful, however, will - as in the case of most international agreements-in the final analysis depend more upon the determination and attitudes of the Member countries than on the technical characteristics of the instrument itself.

As grounds for optimism, the Coffee Agreement establishes all of the institutions, mechanisms, and procedures necessary to provide for the collective solution of both the problems of short-run market instability and long-run disequilibrium. In brief, the tools are there if the parties will use them; the Agreement can work if they have the will to make it work. Moreover, the fact that the countries concerned could reach common understandings and acceptable compromises in as complex a negotiation as the Coffee Conference is itself encouraging evidence of their ability, and hopefully determination, to make the Agreement a success. A continuation of this spirit in the new Organization would go far to bring about meaningful remedies to the persistent problems of the international coffee economy. ${ }^{66}$

provisions, admission of new members, non-members and the use of import controls, the scope of the waiver clause, and choice of personnel and organization of the Secretariat. A number of interesting questions of legal interpretation of the Agreement have also arisen in the past year, and some at least will have to be resolved by the Council at its first session.

${ }^{\circ 5}$ For discussions of the "pros and cons" of commodity agreements, see generally the references cited in note I supra. For a recent criticism of such agreements, see Swerling, Current Issues in Commodity Policy, in Essays in International Finance 22-23 (No. 38, Princeton Univ., June ig62), who attacks commodity agreements for, inter alia, their failure to reach root problems, and their ignoring or disguising of public costs in terms of the proliferation of controls, overpricing, and bad income distribution. The study by International Economic Consultants, Inc., cited in note I supra, at I37, concludes on this issue:

"There is no case for or against commodity agreements per se. The question is a pragmatic one: if it appears that cooperative international action can help to solve a persistent and troublesome commodity problem, then such action should at least be sought-especially in cases where other lines of attack on the problem have failed."

Alternative proposals for the solution of instability in primary commodity export markets include schemes for so-called "compensatory financing" to deal with short-term fluctuations and stabilize export receipts. Various "compensatory financing" plans are currently under study by the United Nations Economic and Social Council, the Organization of American States, the International Monetary Fund, and other international bodies. Arguments have been made for the greater efficiency of direct financial transfers from developed countries as a means of assisting underdeveloped countries.

${ }^{\circ 8}$ See statement by the Honorable Adlai E. Stevenson, U.S. Representative to the United Nations, at the signing of the Coffee Agreement on September 28, I962, 47 Dep'T State Bull. 667 (I962). And see statement by the Honorable Douglas Dillon, U.S. Secretary of the Treasury, at the Ministerial Meeting of the Inter-American Economic and Social Council at Mexico City, October 23, 1962: 
On the other hand, it is clear that the effective operation of the Agreement will face a number of real problems. ${ }^{67}$ First, the negotiations give warning there will be strong and continuing pressures towards unrealistically high quotas as various countries push their unrecognized Conference demands in the International Coffee Council. These pressures may take the form of either requests for waivers or attempts to inflate the Council's annual estimates of consumption and thus total annual export quotas. Dissatisfaction with quotas may lead to attempts at quota evasion or withdrawal from the Agreement.

Second, the Agreement's provisions respecting control of production and stocks may not be as strong as needed to meet the realities of the world coffee situation, and may in practice not be effectively implemented by the Member countries. Failure by the major producing countries to take strong internal measures, including measures to cut back production and encourage economic diversification, will of course leave the basic problem of overproduction unresolved. The Agreement could even have a negative influence in this respect. Thus, by concealing basic market imbalances, it may tend to create a false sense of security leading to the deferring of effective remedial action.

A third problem created by the Agreement is its tendency to protect established producers at the cost of the newer producers who have trees just coming into production. This will undoubtedly give rise over time to considerable tensions. - Fourth, the Council will have to tread a fairly narrow path in its quota decisions in terms of the price effects which its controls will bring about. Clearly, the market must be strengthened if the Agreement is to achieve its objective; but on the other hand, any significant price increases will undoubtedly bring strong consumer reaction and put importing Members under heavy pressure from their public to either increase quotas or leave the Agreement.

Finally, the Agreement contains certain structural rigidities, such as the at least theoretical lack of power of the Executive Board, the Organization's only continuing decisional body, and the complexity of the procedure for electing the Board. It will be difficult for the Organization to operate effectively without some de facto exercise by the Board of greater powers than the Agreement appears to contemplate. ${ }^{08}$

More generally, there is much in the Coffee Agreement and the history of its

\footnotetext{
"[The Coffee Agreement's] great promise lies in the fact that a mechanism now exists through which declines in coffee prices can be arrested and more remunerative levels of earnings achieved. Success will be achieved only if the agreement is operated in an effective manner. The United States stands ready to give serious consideration to any sound project for reducing excess coffee production in the exporting countries, so as to relieve the pressure for quotas in excess of world demand and to make the agreement truly effective."

${ }^{67}$ These problems are of a type more fully indicated by TowLE, op. cit. supra note I, at 739-42, and by Swerling, supra note 65 , at $22-23$. For an alternative suggested solution to the coffee problem based on the use of import quotas and a "rational system of international price discrimination, intended to induce maximum consumption," see Swerling, supra note 65, at 23-24.

${ }^{68}$ See Hexner, supra note 4, at 376: "There is a strong tendency in international organizations, in so far as means of implementation are concerned, to interpret their basic instruments very broadly and to adjust their working arrangements to practical needs without amending their basic instruments."
} 
negotiation which is encouraging from the standpoint of the development of international relations and international law.

Most noteworthy is the increased recognition which the Agreement demonstrates on the part of the importing developed countries for the problems of the economically underdeveloped primary-producing countries. In a very real sense, the quid pro quo for the obligations of the importers in the Coffee Agreement is little more than the possibility which the Agreement offers of assisting the exporting countries in attaining economic and political stability. The statesmanship demonstrated by the importing countries' decision to participate in the Agreement is thus itself a historic development.

Moreover, the Agreement represents a growing international sophistication in evolving collective institutional solutions to complex economic problems on a realistic and practical basis. Thus, the further evolution of the weighted voting concept in terms of the "veto power restriction" formula represents an interesting development in techniques of international legal regulation. There are perhaps few problems of such long-range interest and importance in the field of international law as the working out of some effective way of reconciling the demands of "sovereignty" with the practical realities of differences in national power and stakes in particular international matters. Weighted voting offers interesting possibilities for the attainment of some meaningful concept of international democracy, and the compromises reached in the Coffee Agreement may add to our experience with the possibilities for the flexible use of this technique.

Finally, the International Coffee Agreement demonstrates once again the vast untapped possibilities inherent in international cooperation. Whether the Agreement ultimately succeeds or fails, the fact that such a solution has been at least attempted is itself a significant achievement, and furnishes an important precedent for future collective efforts in the international economic field. 


\section{APPENDIX \\ A SUMMARY OF THE \\ INTERNATIONAL COFFEE AGREEMENT, 1962}

The International Coffee Agreement, 1962, as approved by the United Nations Coffee Conference, is a lengthy, complex, and technical legal document, consisting of a preamble, seventy-four articles grouped into nineteen chapters, and four annexes. For descriptive purposes, it may be functionally divided into five parts: (I) introductory provisions; (2) organizational and administrative provisions; (3) provisions designed to achieve short-term market stability; (4) provisions designed to achieve long-run market equilibrium; and (5) final provisions. ${ }^{1}$

\section{Introductory Provisions}

The introductory provisions explain why the Parties are entering into the Agreement and what they hope to accomplish, and provide the Agreement's definitional and conceptual framework. They "set the stage," as it were, for the substantive provisions to follow.

Preamble. The reasons why the Parties are entering into the Agreement are: (I) the significance of the coffee problem and need for international cooperation in this area; (2) the tendency towards persistent disequilibrium, stock accumulation, and pronounced price fluctuation in the coffee market; and (3) the Parties' belief that, in the absence of international measures, the situation cannot be corrected by normal market forces.

Objectives. The objectives of the Agreement are: (I) to achieve a reasonable balance between supply and demand on a basis which will ensure adequate supplies of coffee to consumers and markets for coffee to producers at equitable prices, and which will bring about long-term equilibrium between production and consumption; (2) to alleviate the serious hardships caused by burdensome coffee surpluses and excessive price fluctuations; (3) to contribute to the development of productive resources and the promotion and maintenance of employment and income in Member countries; (4) to assist in increasing the purchasing power of coffee-exporting countries; (5) to encourage coffee consumption; and (6) in general, in recognition of the relationship of trade in coffee to the economic stability of markets for industrial

\footnotetext{
1 To avoid burdening the text or notes, references to individual articles have, with a few exceptions, been omitted in this summary. However, the arrangement of the chapters of the Agreement is as follows: Preamble; I-Objectives; II-Definitions; III-Membership; IV-Organization and Administration; V-Privileges and Immunities; VI-Finance; VII-Regulation of Exports; VIII-Certificates of Origin and Re-Export; IX-Regulation of Imports; X-Increase of Consumption; XI-Production Controls; XII-Regulation of Stocks; XIII-Miscellaneous Obligations of Members; XIV-Seasonal Financing; XV-International Coffee Fund; XVI-Information and Studies; XVII-Waiver; XVIII-Disputes and Complaints; XIX-Final Provisions. The Annexes are: Annex A-Basic Export Quotas; Annex B-NonQuota Countries of Destination; Annex C-Certificate of Origin; Annex D-List of Exports and Imports in $196 \mathrm{I}$.
} 
products, to further international cooperation in connection with world coffee problems.

Definitions. Twelve terms are defined. These are "coffee"; "bag"; "coffee year"; "export of coffee"; "Organization"; "Council" and "Board"; "Member"; "Exporting Member"; "Importing Member"; "Producing Member"; "distributed simple majority vote"; "distributed two-thirds majority vote"; and "entry into force."2 Some of these definitions perform an important substantive function in establishing the scope of application of the Agreement. Thus, "coffee" is defined in great detail so as to include coffee in virtually every form, ${ }^{3}$ and "export of coffee" is defined to mean any shipment of coffee which leaves the territory of the country where the coffee is grown. Any less broad definition would have left gaps in the quota system. Other definitions, such as "coffee year," "bag," "distributed simple majority vote," and "Member" definitions, establish the meaning of particular technical terms peculiar either to the coffee trade or to the Agreement, in order to assist in its administration and application. Still others, such as "entry into force," defined so as to include both provisional and definitive entry into force, primarily serve a drafting function in permitting the use of a short term in subsequent articles in place of a longer one.

Membership. The concept of "Membership in the Organization," as contrasted with that of "Party to the Agreement," is a key concept in the Agreement. It is used to permit the practical application of the provisions of the Agreement to producing units-either dependent territories or groups of states-which are not identical with the sovereign states which alone have international treaty-making capacity.

The Agreement provides that as a general rule each Party will, together with its dependent territories, constitute a single Member of the Organization-i.e., the Party and Member will be identical. However, two exceptions are permitted. First, a Party which is a net importer of coffee may establish separate membership for any of its territories which are net exporters of coffee. Thus, the United Kingdom, which is a net importer, may designate Kenya, which is a net exporter, as a separate Member distinct from the United Kingdom. Secondly, two or more Parties which are net exporters may form a Member group provided that they declare their willingness to accept responsibility for group obligations in an individual as well as a group capacity and meet certain other conditions relating primarily to the furnishing of evidence that they are capable of meeting membership obligations as a group.

\footnotetext{
${ }^{2}$ Definitions of the various kinds of export quotas were included in the penultimate version of the text prepared by the Drafting Group, but were finally omitted as likely to create more problems than they would solve. It was considered that the Organization could best resolve any definitional problems involving quotas in the context of problems as they arose. As a drafting matter, there is much to be said for erring on the side of too few rather than too many definitions and permitting the definitions of complex concepts to be worked out in the light of actual practice and experience.

"Coffee" is defined to mean "the beans and berries of the coffee tree, whether parchment, green, or roasted, and includes ground, decaffeinated, liquid, and soluble coffee." These other terms are also defined in detail.
} 
Thus, Kenya, Uganda, and Tanganyika may elect to participate jointly in the Organization as a single Member rather than as three separate Members. In each of these cases, the dependent territory Member or Member group will be treated, with certain exceptions, ${ }^{4}$ as a wholly separate participant in the Organization, with its own representation on the Council, votes, and quota.

\section{Organizational and Administrative Provisions- The International Coffee Organization}

In order to administer the Agreement on a continuing basis, some permanent institution is required. A substantial part of the Agreement is essentially a constitution or "corporate charter" creating such an institution and establishing the powers and procedures of its organs and the various commitments of its Members with respect to such matters as privileges and immunities, and finance.

The International Coffee Organization. The Agreement establishes the International Coffee Organization. The Organization will have its seat in London and will function through a Council, an Executive Board, and an Executive Director and Staff.

The International Coffee Council. The supreme authority and governing body of the Organization is the Council, composed of a representative of each Member. The Council is headed by a non-voting elected Chairman and holds regular sessions twice a year. To the Council are entrusted all the major decisions connected with the working of the Agreement. Thus, it is given sole power to determine the annual distribution of votes; approve the Organization's budget and assess Member's contributions; determine and adjust quotas; impose enforcement measures, including the suspension of voting rights or expulsion of a Member; determine production goals and establish a stock policy; waive a Member's obligations; establish conditions for accession; decide disputes and complaints; extend or terminate the Agreement; and recommend amendments to the Members. ${ }^{5}$ It may also establish rules and regulations as required to carry out the provisions of the Agreement. Decisions of the Council (as contrasted with recommendations) are binding upon the Members.

Voting in the Council. The voting formula in the Council is quite complex, combining as it does features designed to give importers and exporters equal weight in determining the decisions of the Organization, and to recognize the different economic importance and status of different countries, yet put some limit on the power of the biggest countries to dominate completely the Organization's policies.

The distribution of votes is based upon a system of equal votes for the group of importers as a whole and the group of exporters as a whole, with the votes within

\footnotetext{
'The exceptions relate to provisions concerning production and stocks, the election of Council officers, quorum requirements, and settlement of accounts with withdrawing Members.

Article I7. The Council's exclusive jurisdiction over these matters is not stated expressly, but rather as a limitation on its power to delegate these matters to the Board.
} 
each of these groups distributed according to the relative trade importance of the Members in that group. Thus, I000 votes are given to all of the exporting Members as a group and I000 votes are given to all of the importing Members as a group, regardless of the number of Members in each group.

At the beginning of each year (or upon a change of membership in the group or suspension of a Member's voting rights), the Council divides the total of rooo votes among each group's Members, as follows: Each Member in that group, regardless of its trade importance, is given five "basic" votes, but the number of basic votes given to all of the Members in that group cannot exceed 150 . In practice, this means that if there are thirty or less Members in that group, each Member will have five basic votes; if there are between thirty and thirty-seven Members, each Member will have four basic votes, and so on. The remaining number of votes in each group, which will be at least 850 , are assigned by the Council: (I) to the exporting Members in proportion to each Member's share in the total basic export quota; and (2) to the importing Members in proportion to each Member's share in the total volume of world coffee imports during the preceding three-year period. However, no Member is permitted to hold more than 400 votes. This provision is, of course, designed to somewhat limit the dominant voting power of the United States, which would otherwise be entitled to more than 400 votes. $^{B}$

Ordinary decisions of the Council require a distributed simple majority vote-i.e., a majority of the votes cast within the importer's group and a majority of the votes cast within the exporter's group, counted separately. More important decisions, such as those concerning quotas, enforcement measures, waiver, and amendment, generally require a distributed two-thirds majority vote-i.e., a two-thirds majority of the votes cast within each group. However, special votes are provided for the revision of quotas in the event of marked price changes in brief periods (a distributed simple majority vote) or in the event of unsual price changes due to artificial "rigging" of the market (a simple majority vote). In order to block the possibility of a veto by either the United States or Brazil in more important decisions requiring a distributed two-thirds majority vote, a special procedure is established whereby, in essence, the negative votes of at least two Members are required to block a proposal to which all other Members within a given group have agreed.

The Executive Board. The Council meets only periodically. The Organization normally functions through a fourteen-member Executive Board which is continuously in session and is composed of representatives of seven exporting and seven importing countries. The Members of the Board are elected each year by the Council. This election is carried out under a complex procedure of successive ballots, with the number of votes any single Member may receive in the balloting for election to the Board limited to 499 . This number of votes received by a particular Member in its election to the Board is quite important, since that Member is permitted to

\footnotetext{
- Brazil would be entitled to about 380 votes.
} 
exercise this number of votes it has received in its election in voting in meetings of the Board.

The Board is permitted to exercise only such powers as are specifically delegated to it by the Council. However, since the Council is specifically prohibited by the Agreement from delegating a long list of its most important powers, the Board's authority is under the terms of the Agreement technically limited to the most routine functions, though it seems unlikely that this technical limitation will be rigidly applied in practice.

The Executive Director. The chief administrative officer of the Organization is the Executive Director, who is appointed by the Council on the recommendation of the Board. $\mathrm{He}$ is assisted by a staff which he may appoint under regulations issued by the Council. Specific provisions of the Agreement are intended to guard against any conflict of interest on the part of the Executive Director or staff, and to assure that they are not subject to special influence from any particular Member.

Finance. During the latter half of each year, the Council approves the budget for the following year. The expenses of the Organization as covered in the budget are then met by annual contributions assessed upon each Member in proportion to its share in the total number of votes in the Council. Contributions are due on the first day of the year. If a Member fails to pay its full contribution within six months of that date, its voting rights are automatically suspended.

Disputes and Complaints. The Council is given final power to decide complaints or disputes referred to it by any Member concerned. In certain circumstances, however, the Council may, before deciding a dispute, be required first to seek the opinion of an advisory panel on the matter. If the Council finds a Member in breach of the Agreement, it may take enforcement measures against that Member, including the suspension of its voting rights and expulsion from the Agreement.

Privileges and Immunities. The Members agree to grant the Organization such legal capacity as is necessary to the performance of its functions in their territories. Moreover, the United Kingdom, as the seat of the Organization, agrees in addition to grant the Organization and its employees certain tax exemptions.

Waiver. The Council may relieve a Member of an obligation under the Agreement which, on account of exceptional or emergency circumstances, force majeure, constitutional obligations, or certain obligations under the United Nations Charter, either (a) constitutes a serious hardship; (b) imposes an inequitable burden on such Member; or (c) gives other Members an unfair or unreasonable advantage. ${ }^{8}$

\footnotetext{
'Disputes will thus be settled through the Council's weighted voting formula. For an interesting comment on this subject, see Metzger, supra note 45, at 408-20. And see generally, Hexner, Interpretation by Public International Organizations of Their Basic Instruments, 53 AM. J. INr'工 L. $34 \mathrm{I}$ (1959).

${ }^{8}$ Article 60 . As is the case with many international economic agreements, such as the General Agreement on Tariffs and Trade (GATT), a number of interesting legal and policy questions will undoubtedly arise under this waiver provision as various Members seek relief from particular obligations. The wording of article 60 is itself quite broad and does not appear to expressly except any obligations from the potential reach of the waiver authority. However, it may be argued that there are implied
} 
Information and Studies. The Organization is to act as a center for the collection, exchange, and publication of statistical and technical information relating to coffee, and may require the Members to furnish such information. It may also promote and undertake studies related to coffee.

\section{Provisions Relating to Short-run Market Stability- Regulation of Exports and Imports}

The Agreement attempts to provide an immediate short-run solution to the problems of market instability and price decline through the establishment of a comprehensive system of administered export quotas. This system is designed to limit the supply of coffee offered on the international market by exporting Members to that quantity which the market will absorb at a particular level of prices. The Agreement does not contain any specific price provisions; nor does it directly seek to regulate coffee prices. However, it is provided that the operations of the quota system are in general to be directed to "assuring that the general level of coffee prices does not decline below the general level of such prices in 1962." In order to make the quota system effective and to prevent its violation, the Agreement also requires importing Members to establish certain types of measures relating to coffee imports.

Export Quotas. Three kinds of quotas are provided for by the Agreement: (I) "basic export quotas," which are essentially a basis for the division of quotas rather than actual quotas; (2) "annual export quotas"; and (3) "quarterly export quotas."

"Basic export quotas" are established for each exporting Member as specified in Annex A. ${ }^{10}$ These basic quotas are not subject to revision for three years (i.e., until September 30, 1965), and unless revised by agreement at a review session which is then to take place, will remain in effect for the full term of the Agreement. ${ }^{11}$ These basic export quotas do not represent the actual amount of exports permitted each Member in any given year, but rather determine that Member's proportionate

exceptions such as the automatic penalties imposed for exceeding quotas or the special upper limit to permitted adjustments in quarterly quotas specified in article $34(4)$.

${ }^{\circ}$ Article $27(2)$. See also article $27(3)$, in which the Members agree on the desirability of assuring to consumers prices which are equitable and which will not hamper a desirable increase in consumption; and article 42 which permits regional and inter-regional price arrangements among exporting Members so long as they are consistent with the general objectives of the Agreement and are registered with the Council.

${ }^{10}$ The grand total of basic export quotas is $45,587,183$ bags (I bag equals 60 kilograms, or about 132 lbs.). This total is divided among thirty-six exporting countries. Some representative basic export quotas are (in bags): Brazil-18,000,000; Colombia-6,orI,280; Ivory Coast-2,324,278; Portugal2,188,648; Uganda-I,887,737; Mexico-I,509,000; El Salvador-I,429,500; Guatemala-r,344,500; Indonesia-1,I76,000; Venezuela-475,000; India-360,000; Honduras-285,000; Yemen-77,000. In recognition of particular problems of the Dominican Republic, Haiti, the Republic of the Congo (Léopoldville), and Rwanda and Burundi, footnotes to Annex A provide that these countries can export certain specified amounts in addition to their assigned basic export quotas.

${ }^{11}$ The provision for continuing existing basic export quotas, if agrecment on new quotas was not reached at the 1965 review session, was to avoid the situation which occurred in the case of the present Sugar Agreement of 1958 . Under the terms of that Agreement, the quota provisions expired after three years, and, since a $196 \mathrm{I}$ review session was unable to agree on new quotas, the Agreement, though technically in effect until 1963 , is for most practical purposes inoperative. 
share in the total annual export quotas established by the Council each year, which is an important fact in itself.

The actual level of exports permitted each exporting Member in a given year is its "annual export quota," which is determined by the Council as follows. Prior to the beginning of each year, the Council adopts an estimate of total world imports of coffee and an estimate of probable exports from non-Member countries for that year. In the light of these estimates, it then fixes annual export quotas for each exporting Member which are to be the same percentage for all exporting Members of their basic export quotas as specified in Annex A. Presumably, the Council will calculate the proportion which its estimate bears to the total basic export quotas set out in Annex A (about 45.6 million bags) and will then establish the annual export quota of each exporting Member as that same proportion of its basic export quota. For the coffee year $1962-63$, when the Council will not have been in existence prior to the beginning of that year to establish quotas, annual export quotas for Members are established by the Agreement itself at ninety-nine per cent of basic export quotas.

In order to ensure orderly marketing throughout the coffee year, and to prevent price-depressing effects due to seasonal fluctuations in supply and demand, the Council will, after it establishes the annual export quotas, also establish quarterly export quotas for each exporting Member, which are to be as nearly as possible twenty-five per cent of its annual quota.

Both annual and quarterly export quotas are subject to adjustment in the light of market developments during the period. Annual export quotas may be adjusted by varying the percentage of basic export quotas fixed for Members by the Council prior to the beginning of the year. This adjustment is always applied uniformly between countries. Quarterly export quotas are for the most part to be applied uniformly between countries on a pro rata basis, but in exceptional circumstances are subject to some individual adjustment within specified limits. As a special protection to importing Members against over-restrictive quotas resulting in substantial price increases, if significant price rises or falls occur within brief periods, Members may request a special meeting of the Council, which may, by a distributed simple majority vote (in contrast with the distributed two-thirds majority vote required in connection with most quota decisions), revise the total level of quarterly export quotas then in effect. Where such sharp price falls appear to be the result of market-rigging arrangements, the Council may decide on corrective measures by a simple majority vote (in contrast with the distributed majority vote required for all other decisions). This means that any producers engaging in market rigging will less likely be able to block corrective action.

In order to avoid market disturbances resulting from any attempts to unload stocks prior to the coming into effect of the Agreement, a transitional provision provides that any exports of coffee by a country after October $x, 1962$ will, at the 
time the Agreement comes in effect, be charged against its annual export quota. The Council may, when it comes into existence, make such modifications in the quotafixing procedure for the first year as may be necessary to implement this provision.

Sanctions. Exporting Members undertake not to exceed their annual or quarterly quotas and agree to adopt such measures as may be required to ensure full compliance with the quota provisions of the Agreement. The Council may, if necessary, request such Members to adopt additional measures. Failure by a Member to comply with its export quotas exposes it to compulsory penalties increasing in severity with the number of violations. Thus, if a Member exceeds its quarterly quota once, the Council must deduct the amount of that excess from one or more of that Member's future quotas. For a second violation, the compulsory deduction is equal to twice the excess shipments. If the Member exceeds its quota a third or more times, the Council may expel the Member from the Agreement.

Coverage of the Quota System. The quota system is intended to cover almost all shipments of coffee by exporting Members. Thus, shipments of coffee in every form are counted as within the quotas. The Agreement does, however, permit certain categories of "ex quota" shipments which, so long as the applicable conditions are met, are not counted for quota purposes.

The most important exception relates to exports to thirty-one particular "new market" areas and countries listed in Annex B. These "new market" countries are characterized by low per capita coffee consumption and a considerable potential for market expansion. Exports to such countries are not charged to quotas. However, the aggregate quantities of coffee shipped to them by all exporting Members are not to exceed a quantity which will be established by the Council each year as the estimated amount of imports for internal consumption of such countries. A variety of reports and checks are required in connection with such shipments to ensure that there is no trans-shipment from "new markets" to traditional markets. If the Council discovers any such re-exports to traditional markets, it may charge them to the quota of the exporting Member originally exporting that coffee to the "new market." If re-exportation from that "new market" continues to occur, the Council may strike the "new market" country from the list of permitted "ex quota" destinations.

Certain other exceptions are also provided by the Agreement. First, any exporting Member whose average annual exports of coffee for the preceding three-year period were less than 25,000 bags is wholly exempt from the quota provisions. Second, shipments of coffee from a dependent territory of a Member to its metropolitan territory are not charged to quotas unless the dependent territory has been designated as a separate Member of the Organization. Finally, exports of coffee

23 Article 40. The "new market" countries are situated primarily in the Near East, Far East, Eastern Europe, and Southern Africa. The Communist bloc is heavily represented, with the USSR, Poland, Hungary, Rumania, Mainland China, North Korea, and North Viet Nam included on the list. Article 40 is somewhat ambiguous as to whether the Council's estimates and corresponding basis are to be on an aggregate or a country-by-country basis. Exports in excess of the quantity set by the Council are apparently not chargeable to quotas. 
for other than human consumption, or for humanitarian purposes, are not counted for quota purposes.

Certificates of Origin and Re-Export. The quota system is policed through an international certification system. Every shipment of coffee from a Member to a Member must include as part of the regular shipping documents either a Certificate of Origin or, if the shipment is a re-export, a Certificate of Re-Export. Such certificates must establish the country of origin of the coffee, be in a prescribed form, and be issued by a qualified agency. The issuing Member must furnish a copy of each certificate to the Organization. Importing Members agree to prohibit the entry of coffee from any Member not accompanied by such a certificate, and periodically to render reports on coffee imports to the Council as a means of checking compliances with quotas.

Restrictions on Imports from Non-Member Countries. One problem which a quota agreement faces is that non-Members may attempt to take advantage of the limitation of exports by Members by increasing their own exports. The possibility of realizing such gains at the Members' expense may even lead some countries to stay out of the Agreement. In order to guard against this possibility, importing Members undertake that, if three months after the Agreement enters into force, or at any time thereafter, Members of the Organization represent less than ninety-five per cent of world exports in Ig6r, each Member will limit its imports from nonMember countries as a group to a quantity not in excess of its average annual imports from such non-Member countries as a group during the three years prior to the Agreement's entry into force. The Council may, however, either defer the imposition of such limitations or may, in certain circumstances, require the imposition of such limitations even though the Members of the Organization represent more than ninety-five per cent of world exports. The Council may also recommend additional limitations to be placed upon imports from non-Member countries if it finds such action necessary. The Council may suspend the voting rights of any importing Member failing to comply with these obligations.

\section{Provisions Relating to Long-Run Equilibrium-Reduction of Production and Stocks and Increase in Consumption}

The ultimate objective of the Agreement is the achievement of long-run equilibrium between production and consumption. This requires, on the one hand, efforts to reduce existing high levels of production and stocks through such measures as limitation of plantings and economic diversification. It requires, on the other hand, efforts to increase consumption, both by increasing consumer desires for coffee and by reducing various artificial obstacles to consumption, such as tariffs, import quotas, and internal taxes. While the Agreement addresses itself to both of these problems, it does so in a more general and less positive way than is the case with respect to short-term coffee problems. Principles and goals rather than definite procedures are 
provided, obligations are less defined and more tenuous, and sanctions are extremely limited.

Measures to Increase Consumption. In order to promote coffee consumption, existing advertising and promotion campaigns of the exporting Members may be continued under the Agreement. For this purpose, the Council may establish a special committee to be known as the World Coffee Promotion Committee. However, funds for promotion will be assessed only from exporting Members.

In order to reduce artificial barriers to consumption, Members undertake to investigate ways and means to reduce progressively, and eventually to eliminate, obstacles to increased trade and consumption, and to inform the Council of the results of such investigations within the first eighteen months after the Agreement enters into force. Moreover, they agree to take account of the results of such Council review in the adoption of domestic measures and in proposals for unilateral action, and to review the entire subject further during the third-year review of the Agreement. ${ }^{13}$

Production and Stocks. The Agreement does not require specific production and stock controls. However, the Council must, within one year after the Agreement enters into force, recommend both production goals for each Member and the world as a whole, and a general stock policy, so that supply and demand may be brought into natural balance during the course of the Agreement. Producing Members undertake to adjust their production of coffee to the amount needed for domestic consumption, exports, and stocks as established by the stock policy recommended by the Council. It is made clear, however, that each Member concerned is to be entirely responsible for the national policies and procedures it chooses to achieve these general objectives. The Members must periodically report to the Council as to the measures which they are taking in these respects, and the results obtained.

Limited sanctions are provided for failure to take any meaningful action with respect to the limitation of production. Producing Members failing to adopt programs to adjust their production to production goals recommended by the Council, or having ineffective programs, may be deprived by the Council of quota increases to which they would otherwise be entitled under the operation of the Agreement. ${ }^{14}$

In addition, importing Members undertake, consistent with their general policies regarding assistance, to cooperate on a technical, financial or other basis with the producing Members in their plans for limiting the production of coffee.

International Coffee Fund. The Council may establish an International Coffee Fund to further the objective of limiting the production of coffee and to assist in the

\footnotetext{
${ }^{13}$ Article 47. A reading of the text of this article reveals the long and difficult negotiations which went into its deveolpment.

1" Since these provisions apply to "producing Members" rather than to "exporting Members," some importers, such as the United States (which produces relatively small amounts of coffee in Hawaii and Puerto Rico), are theoretically covered. However, since importing countries do not have quotas, the sanctions for non-compliance would be inapplicable.
} 
achievement of the other objectives of the Agreement. However, contributions to the Fund are to be wholly voluntary.

\section{Final Provisions}

The so-called "final clauses" set up the legal housekeeping for the Agreement itself-the conditions for its entry into force and termination; the "ins and outs," which provide how individual countries can come into or leave the Agreement; and the method by which the Agreement may be amended. The "final clauses" also provide that the "housekeeper" or depositary of the Agreement is to be the Secretary General of the United Nations. ${ }^{15}$

Signature and Ratification. The Agreement is open for signature from the time of its adoption by the Conference until November 30, 1962. Any Government invited to the Coffee Conference and the Government of any State represented before independence as a dependent territory at the Conference is eligible to sign. Signature alone, however, is not enough to make a country a party to the Agreement, entitled to share in its rights and obligations. Governments may become actual Parties to the Agreement only by subsequently depositing instruments of ratification with the depositary not later than December 3I, 1963. The instruments of ratification are to indicate whether the Government is joining as an importing or an exporting Member.

Entry Into Force. The Agreement definitively enters into force when Governments representing at least twenty exporting countries having at least eighty per cent of world exports of coffee in the year I96r, and Governments representing at least ten importing countries having at least eighty per cent of world imports of coffee in the year 196r, deposit instruments of ratification or acceptance with the depositary. ${ }^{16}$ For the purpose of assisting the depositary (the UN Secretariat) in knowing when these percentages have been met, Annex $\mathrm{D}$ provides agreed figures as to the amount and percentage shares of the various countries in world exports and imports in I96r. In effect, the requisite percentages cannot be met and the Agreement cannot

\footnotetext{
${ }^{15}$ The depositary of an international agreement has an arduous, thankless, and expensive task. The printing and circulation of final texts may alone run into thousands of dollars, and the routine of receiving and forwarding notifications from and to a hundred countries is exacting and difficult. For this reason, the United States and the United Kingdom, which had assumed this burden with respect to a great number of treaties and international agreements, were not anxious to act also as depositary for the Coffee Agreement. In order to distribute this burden more equitably among nations, it was suggested that the UN Secretariat act as depositary, even though it had not usually acted as depositary for such economic agreements. The Secretariat graciously accepted this task, though perhaps with some private reluctance.

${ }^{10}$ Article $64(x)$. By way of contrast, the requirements as to deposit of instruments of ratification or notification for entry into force of other commodity agreements are: Wheat-Governments holding not less than $\% 3$ of the votes of exporting countries and $/ 3$ of the votes of importing countries (Art. 35(5)); Sugar-Governments holding at least $60 \%$ of the votes of importing countries and $70 \%$ of the votes of exporting countries (art. 4I(6)); Tin-9 consuming countries holding at least 500 votes and 6 producing countries holding at least 950 votes (art. XXI(3)). In each of these cases, unlike the Coffee Agreement, votes are specifically allocated in the applicable agreement.
} 
come into force until ratified by the United States and Brazil, since these countries represent such a large share in world imports and exports.

The parliamentary processes required to secure formal ratification of treaties and international agreements are normally quite involved and time-consuming, and in the case of some countries, a year or more may elapse before that country is in a position to deposit an instrument of ratification. Therefore, in order to permit the Agreement to come into operation more quickly than would otherwise be the case, a procedure is provided whereby the Agreement may provisionally enter into force with something less than formal ratification by the requisite numbers and percentages of countries. Thus, for the purpose of provisional entry into force, a notification by a signatory Government containing an undertaking to seek ratification or acceptance in accordance with its constitutional procedures as rapidly as possible, which is received by the depositary not later than December $30, \mathrm{Ig}_{6} 3$, is to be regarded as equal in effect to an instrument of ratification or acceptance. However, it is understood that any Government which gives such notification will provisionally apply the Agreement and be provisionally regarded as a Member, and must therefore be prepared to accept these responsibilities if it uses this procedure. ${ }^{17}$

Formal ratification by December 3I, 1963 is still required, however, for definitive entry into force, and if on that date the Agreement has not definitively entered into force, those Governments which have by that date ratified it may consult together to decide what action the situation requires, and may by mutual agreement decide that the Agreement shall enter into force among themselves. ${ }^{18}$

The situation as to entry into force is therefore as follows. Sufficient numbers of countries to potentially meet the required numbers and percentages for entry into force have to sign by November 30,1962 , since signature is a condition precedent to ratification. This has in fact already occurred. Then, if the requirements are

${ }^{17}$ For somewhat similar "provisional entry into force" provisions, see articles $35(6)$ of the Wheat Agreement and article 4I(6)(ii)-(iv) of the Sugar Agreement. The stimulus for the use of such a provision in the Coffee Agreement came from Brazil which was anxious to get the Agreement into operation as quickly as possible, had existing legal authority to carry out its obligations prior to ratification, but contemplated that it might require at least a year to secure formal ratification by its legislature. The United States, on the other hand, indicated at the Conference that it did not intend to assume obligations under the Agreement until it had secured further legislative authority, and hence would not utilize the notification device. In fact, as events developed, it ultimately became necessary for the United States to resort to the notification procedure. The status of "provisional" Members is quite ambiguous, and is perhaps better defined in terms of moral obligations than legal ones. These provisions are also complex and extremely difficult to explain to non-specialists. It would be useful if someone could devise a better technique for handling this problem.

${ }^{28}$ Though usual in commodity agreements, this provision is somewhat confusing, since it appears to contradict the specific requirements for entry into force otherwise established. Such a provision was considered necessary, however, to guard against the possibility that ratifications might fall just short of the specific requirements. In the absence of this provision, the Agreement could not in such case be put into force except by resubmitting a "new" agreement with slightly lower requirements to the legislatures of many of the countries concerned. In the United States, for instance, Senate approval of participation in an agreement requiring ratification by countries representing $80 \%$ of world trade would not constitute approval of such participation in an agreement ratified by countries representing only $79.9 \%$ of world trade, unless a clause permitting entry into force in such case was specifically included in the instrument submitted to the Senate. 
met before December 31, $\mathrm{I}_{9} 6_{3}$ by a combination of ratifications and notifications of intent to seek ratification, the Agreement will provisionally enter into force until December 30, I963. This has also occurred (on July I, I963). By December 3I, I963, however, the requirements must be met through formal ratifications alone in order to bring the Agreement definitively into force. This has not yet taken place. If by that time the Agreement is not definitively in force, it lapses, even if it was previously provisionally in force, unless the Governments which have ratified by that date agree to bring it into force among themselves.

The Secretary General of the United Nations is requested to convene the first session of the Council in London within thirty days after it enters into force.

Accession. Accession is the route which a Government must use to become a Party to the Agreement if it has not signed the Agreement by November 30, Ig62, or if it is a signatory but has failed to ratify the Agreement by December 3r, 1963. The Government of any State Member of the United Nations or of any of its specialized agencies and any Government invited to the Coffee Conference is eligible to accede to the Agreement, but only upon conditions established by the Council. If the acceding Government is an exporting country listed in Annex $A$ as having a basic export quota, the Council may vary its quota. ${ }^{19}$ If the country is not so listed, the Council may establish such a quota for it.

Reservations. No reservations may be made to the Agreement. ${ }^{20}$

Territorial Application. Any Government may by notification to the depositary declare that the Agreement extends to any of its dependent territories, or that it ceases to so extend, or that such a territory is joining the Organization as a separate Member or part of a separate Member group. If any dependent territory to which the Agreement is so extended later becomes independent, it may automatically become a separate Party to the Agreement and Member of the Organization by so notifying the depositary within ninety days of its date of independence.

Withdrawal. The Agreement provides for two quite different types of withdrawal-voluntary and compulsory. A Party may voluntarily withdraw from the Agreement effective at any time after December 31, I963, but may not voluntarily withdraw before that date. Ninety days' notice is required. Compulsory withdrawal, on the other hand, is the harshest sanction provided by the Agreement, and is in effect expulsion. If the Council determines that any Member has failed to

\footnotetext{
${ }^{10}$ The possibility that quotas might be decreased was an implied threat to any exporting country which might contemplate holding off becoming a party to the Agreement through signature and ratification, in order to see how things developed, knowing that it could always become a party later through accession. A country may still postpone joining the Agreement, but only at the risk of receiving a less favorable quota.

${ }^{20}$ The strictness of the reservation article is balanced by the broad reach of the waiver article. It is for the depositary initially to decide what constitutes a reservation. This can be difficult since countries sometimes attempt to attach statements of "intention" or "understanding" to their ratifications, which may be reservations in substance though not in form. Under the rule of the Genocide Case, [195I] I.C.J. Rep. I5, 29-30, each of the parties must in the last analysis decide whether such a statement amounts to a reservation, and whether to treat the country in question as a party to the Agreement.
} 
carry out its obligations under the Agreement and that such failure significantly impairs the Agreement's operation, it may require that Member to withdraw from the Agreement. Provision is made for the settlement of accounts with withdrawing Members in each case.

Duration and Termination. The Agreement is to remain in effect until the end of the fifth full year after it enters into effect, but the Council may either extend it or terminate it at an earlier date. ${ }^{21}$

Review. The Council is directed to hold a special session during the last six months of the coffee year ending September 30, 1965, in order to review the Agreement. This will presumably be at the same time when the basic export quotas set out in Annex A will be open for review and revision.

Amendment. The Council may recommend amendments to the Members. Since no alternative method is provided, this would appear to be the only way (other than a new diplomatic conference) in which amendments can be proposed. Any amendment so recommended will become effective one hundred days after notification of its acceptance is given to the depositary by Parties representing at least seventy-five per cent of the exporting Members holding at least eighty-five per cent of the exporting Members' votes, and at least seventy-five per cent of the importing Members holding at least eighty per cent of the importing Members' votes. Any Party which has not accepted the amendment by the time it becomes effective will be regarded as ceasing to participate in the Agreement as of that date. ${ }^{22}$

2x The Senate Foreign Relations Committee, in the Hearings on the Agreement, indicated its view that the United States Government should not support in the Council the extension of the treaty beyond five years without first re-submitting it to the Congress for its examination and approval. Hearings, stupra note 8 , at 67.

${ }^{23}$ Amendment provisions can create serious difficulties for a Government seeking ratification of an agreement from its legislature, and have to be closely watched. The United States Senate, for instance, is reluctant to accept any agreement which may conceivably, as through loose amendment provisions not dependent on United States consent, bind the United States to obligations which were not before the Senate at the time of ratification and which the latter has not had a chance to examine. The Agreement provides two safeguards in this respect: (I) a party may voluntarily withdraw from the Agreement on ninety days' notice-i.e., before the end of the roo day period after which an amendment it disapproves of comes into effect; and (2) even if a disapproving country does not take this course, it is automatically expelled from the Agreement and thus not bound by that provision. Suggestions that the Agreement distinguish between "substantive and procedural" or "important and unimportant" amendments in this respect appeared to the Legal Group to be unworkable. 